\title{
Social constraints in cross-boundary collaborative deer management
}

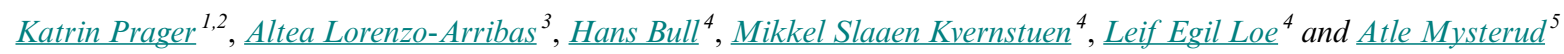

\begin{abstract}
The complex interactions between different spatial, temporal, and functional scales in social-ecological systems are recognized as a key challenge in sustainable management of natural resources. We analyze scale mismatches using the example of migratory red deer (Cervus elaphus) management. Hunting practices and organization of hunting are shaped by the social and institutional context rather than the biology and space use of the species. The collaboration among landowners across property boundaries is a potential solution to address scale mismatches but a number of social constraints need to be taken into account. Based on data from a survey of attitudes and perceptions of 509 Norwegian landowners we found a number of social constraints including differing interests and objectives for deer management, land tenure arrangements, weak links between actors at different levels, lower satisfaction with current deer management and cooperation at the higher (municipality) level, information asymmetry, and different perceptions of benefits and costs of cooperation. For example, $73 \%$ of respondents were satisfied with current management at the hunting field level (smallest management unit) but only $43 \%$ at the municipality level, which represents unit sizes necessary for deer management at the population level. Seventy percent of respondents hunt mainly for enjoyment and meat whereas $30 \%$ hunt to reduce crop damage; hence aggregation into larger management units may increase internal conflict among landowners with different objectives. Our results suggest that coordination of management across property boundaries is a more realistic aim than merging of units. Given that income from hunting in Norway is generally low, we anticipate that financial incentives are unlikely to have a large impact on landowners' willingness to cooperate. Instead, we make suggestions for enhancing existing nested governance arrangements and institutional interplay to support scale alignment by means of developing shared management objectives, and creating learning and knowledge sharing opportunities facilitated by an intermediary.
\end{abstract}

Key Words: cooperation; hunting; intermediary; red deer management; scale mismatch

\section{INTRODUCTION}

The complex interactions between different spatial, temporal, and functional scales in human-environment systems are recognized as a key challenge in sustainable management of natural resources. Scale mismatches can result from the internal dynamics of social and ecological systems respectively, or from the dynamics of the social-ecological interaction. The social processes that lead to scale mismatches relate to land tenure, which is further influenced by changes in human populations, governance, technology, infrastructure, and values. The ecological processes involve changes in the resource base through, e.g., trophic cascades, disease, reductions in productivity, and changes in the abiotic environment (Cumming et al. 2006). Such interactions have been discussed as cross-scale dynamics (Cash et al. 2006), and the consequences of scale mismatches for the socialecological system such as loss of landscape heterogeneity, degraded systems, and decreased resilience, have been identified (Young 2002, Cumming et al. 2006). Among the approaches proposed to resolve scale-mismatches is nested governance, where decision-making is distributed among a hierarchy of institutions (Ostrom 1990, Marshall 2008). Nested approaches that loosely couple community-based resource governance and higher-level institutions are favored over highly complex structures (Berkes and Folke 1998). Enduring questions are: Who should undertake what activities at which level? And how can institutions work collectively across multiple scales? Such questions have been addressed to some extent (Wyborn and Bixler 2013) but there remains limited evidence on how to address scale mismatch problems. In this paper we analyze scale mismatches using the example of partially migratory red deer management, and identify possible ways to address these scale mismatches based on an analysis of ecological, social, and institutional factors.

The migratory movements of large herbivores are one example of social-ecological processes leading to scale mismatches. Harvesting through recreational sport hunting is the most widely applied method to regulate large wildlife species and represents a direct form of deer management (Hothorn and Müller 2010). In the case of red deer (Cervus elaphus), the species was protected in many European countries in earlier decades. In combination with other factors, the availability of forage associated with changes in land use and agricultural management, as well as the direct management of deer, has resulted in a considerable increase in red deer numbers and harvests (Gill 1990) and now the challenge is how to control many of the populations (Milner et al. 2006). Increasing numbers and higher density of populations has led to large economic, sociocultural, and ecological impacts on landscapes (Appolonio et al. 2010), for example, foraging damage on agricultural land, in forests and in conservation areas (Gerhardt et al. 2013), as well as increasing road traffic accidents (Mysterud 2004).

Hunting rights in Europe are generally held by the landowner (Appolonio et al. 2010). The mobile nature of deer as a natural resource means that deer are not uniquely associated with and owned by one landowner but move across the landscape; hence deer are considered res nullius (MacMillan and Phillip 2010).

\footnotetext{
${ }^{1}$ University of Aberdeen, ${ }^{2}$ James Hutton Institute, ${ }^{3}$ Biomathematics and Statistics Scotland, Aberdeen, ${ }^{4}$ Norwegian University of Life Science, Department of Ecology and Natural Resource Management, ${ }^{5}$ Centre for Ecological and Evolutionary Synthesis (CEES), Department of Biosciences, University of Oslo
} 
Fencing is expensive and impracticable in many upland and mountainous regions such as Norway and Scotland, and may have other unforeseen negative consequences for the ecosystem. Migratory deer in particular will thereby cross multiple property boundaries, depending on the size of the landholdings, which makes population-level management difficult to achieve. Even administrative units such as municipalities only cover up to threequarters of the annual ranges (Meisingset et al. 2018). Scale is an issue that brings additional complexity to population management because it increases the number of stakeholders and hence the diversity of interests and objectives to be considered and reconciled. Deer populations are no longer managed only for conservation or for hunting objectives, but societies aim to balance deer populations and other landscape goals. Managing a common property resource such as red deer makes understanding social factors, alongside ecological ones, important in designing effective management strategies (Austin et al. 2013).

We aim to identify possible ways to address the scale mismatches arising from red deer management. We focus on social constraints to cross-boundary, collaborative deer management and explore collaborative management options through a survey of attitudes and perceptions of landowners regarding deer management and cooperation. Recognizing that scale mismatches cannot usually be solved at any single level or scale in the social system, we also consider the social structures that currently govern the management of deer at various administrative levels. We explore a suggestion from the literature for addressing scale mismatches: how nested governance arrangements and institutional interplay can be enhanced to support scale alignment.

\section{SCALE MISMATCHES IN SOCIAL-ECOLOGICAL SYSTEMS}

Spatial, temporal, and functional scale mismatches in the socialecological system can be observed in the example of red deer management in Norway.

Spatial mismatches will occur when the spatial scales of
management and the spatial scales of ecosystem
processes do not align appropriately... Temporal
mismatches will occur when the temporal scales of
management and the temporal scales of ecosystem
processes do not align appropriately... Functional
mismatches will occur when the functional scales of
management do not align appropriately with the
functional scales of ecosystem processes (Cumming et
al. 2006).

The functional scale refers to the magnitude or rate of a process of interest such as production, consumption, or a management manipulation.

The scale mismatch is exacerbated by deer as a mobile resource. The migration patterns have likely evolved over time as population density of red deer have increased. Based on spatial comparisons, it is documented that most red deer are migratory in areas recently colonized and with low population density, while the proportion of migrants is lower (down to $\sim 50-60 \%$ ) in areas with high population density (Mysterud et al. 2011). Given the migratory nature of red deer, ecologists have provided evidence to show that there is a considerable mismatch between animal space use and current management units. Only $12 \%$ of the management units studied were sufficiently expansive to cover migratory routes in females (only 4\% for males; Meisingset et al. 2018). Therefore, there is an argument to increase the size of the management units in areas where seasonal migratory animals represent a substantial proportion of the population. One option would be to align management units with the administrative boundaries of Norwegian municipalities. In this case, the median municipality size could potentially cover $70 \%$ and $62 \%$ of the annual ranges for seasonal migratory females and males, respectively (Meisingset et al. 2018). In terms of the temporal scale, autumn migration of deer in Norway occurs from late August throughout September, in general from higher elevation inland areas to coastal wintering areas. This implies a redistribution of red deer from inland landowners to coastal landowners during the hunting season from 1 September to 23 December (Skonhoft et al. 2013). Even though the understanding of migratory behavior has improved, scientists struggle to pin down exactly what the optimum size (and shape) of a functional management unit would be, not least because the degree of mismatch between range use and management units depends on season and landscape type.

In addition, there is a trade-off in choosing the right scale. Although a larger scale (such as a municipality) is preferable to accommodate the ecological processes, effective collaborative structures operate at smaller scales. Social networks such as groups of landowners managing deer rely on personal relationships, face-to-face contact and trust. These are more easily cultivated at a smaller, local scale (Ostrom 1990, Wyborn and Bixler 2013). The larger the management units, the more people are generally involved, and the greater the distances that people have to travel to sustain relationships, e.g., attending meetings. Westerink et al. (2017) noted in the context of agri-environmental collaboratives that larger groups must find ways to avoid the negative impact of disconnectedness on member involvement and commitment. Larger groups must also combine the professionalism required for spatial coordination with the social capital required for the effective functioning of the group.

According to Cumming et al. (2006), the social processes that lead to scale mismatches relate to land tenure, i.e., how property rights to land are allocated within societies. Land tenure is further influenced by governance, infrastructure, and (individual and collective) values. In order to address the spatial scale mismatch between the size of landholdings and the range of migratory deer, cooperation or coordination of management activities is necessary. Meisingset et al. (2018) suggest that because of the extensive movements especially of male deer, coordination of management aims may provide a more realistic avenue than increasing sizes of local management units. The question is who should undertake this coordination, and in what way? The question arises whether this should be the responsibility of the groups of landowners, the municipality, or another entity. Similarly, it is unclear whether the appropriate mechanism for coordination is through plans, incentive payments, or mandatory collective schemes.

Both coordination and cooperation activities result in transaction costs and benefits. Transaction costs are made up of "the costs associated with searching for information, searching for partners in collective action, drawing up and enforcing contracts, and 
building up networks and social capital ... [and] transaction costs for resource management involve negotiations over shared values, objectives and consensus around sustainability, and involve social interaction" (Adger et al. 2005). Benefits may mean there are more animals to harvest, reduced browsing damage, fewer deer-related road-traffic accidents, and less deer impacts on conservation woodlands (Austin et al. 2013). The uneven gains from cross-scale interactions are themselves an integral part of social-ecological system governance (Adger et al. 2005). In situations where ecological resources deliver an unequal distribution of benefits and costs among stakeholders (Austin et al. 2010) this will act as a barrier to collaborative management. A further barrier is diverging management objectives, e.g., increasing vs decreasing the deer population. We therefore investigated landowner attitudes to hunting, i.e., their main motivation to hunt; the income that they generate from hunting; their views on current deer management and the level of the deer population; as well as their attitudes and perceptions on barriers, and the benefits of collaboration.

\section{CASE STUDY AND METHODS}

\section{Case study background: red deer management in Norway}

Red deer management in Norway has been described as being undertaken in a well-defined management system, typically consisting of many landowners operating in a cooperative manner, with the goal of maximizing the present-value huntingrelated income while taking browsing and grazing damages into account (Skonhoft et al. 2013). However, the social processes and institutions are more complex and multilayered than this description suggests.

There are several institutional levels at which red deer management is organized. Some are informal, while others represent legal entities. These levels may be described as follows: At the lowest level, several landowners are part of a hunting field (jaktfelt). This is a historic unit at which hunting quotas were allocated, but nowadays it is an informal unit consisting of landowners that hunt together and collaborate regarding the practical aspects of hunting.

Several hunting fields together make up a vald, the local management unit (LMU). This is self-organized, i.e., a landowner or a group of landowners in a hunting field decide to join a vald. Although the municipality does not delineate valds, quotas are determined by the municipality for each vald. Due to this bottom up, self-organized approach, the size of the vald and whether its orientation suits migratory deer is determined by the group of landowners, which depends on their awareness of deer management and their preferences. The valds set up their own rules for when members can join or leave, and the involvement of the municipality is restricted to discouraging the hunting fields from leaving the vald. Landowners may choose to retain their own hunting field for the practical aspects of hunting, but they share quota with neighboring landowners in a vald. The municipalities are interested in establishing and maintaining larger valds because it reduces their transaction costs and supports deer management across larger areas.

Individual valds can make use of the opportunity to set up their own multiannual population plans to guide deer management. At the next level up, several valds may jointly set up a common population plan. Hence, a multiannual population plan can be linked to either a single vald or a population plan area (bestandsplanområde), with the former being the most common. Collaboration in terms of producing multiannual population plans provides some advantages to landowners. They gain more flexibility in terms of population management within the plan period. For example, they can influence on the distribution of licenses between hunting fields, or transfer unused licenses from one year to the next within the plan period. This population plan area is not a legal entity, and any vald can decide to join or leave (even if that causes, for example, a gap in the middle of a previously coherent area). Despite this population plan, the number and type of deer harvested is reported by each vald separately. The costs associated with drawing up a population plan are borne by the vald members. They can apply to the municipality to cover some of the costs associated with meetings and drawing up the population plan. Multiannual population plans (3-5 years) are becoming more common. These plans must describe the number and proportion of each sex and age category of deer proposed to be harvested during the plan period, and be consistent with the management goals of the municipality. Ideally, the plans take into account the current deer population in a given area, which is determined based on success of last fall harvest, the number of deer seen by hunters, and sometimes spring counts on pastures (Mysterud et al. 2007).

The final institutional level is the municipality. The municipality allocates sex- and age-specific quotas to valds that have not set up their own multiannual population plan. The number of licenses included in the population plan is strictly linked to the area covered by the vald/population plan area. The number of deer licenses that can be given to an area is defined by municipal regulations, but a national regulation specifies the degree of flexibility that can be practiced around the defined municipal regulation. Whereas previously the quota was based on the size of a given vald, it is becoming more common to allocate the quota based on the population plan. There are normally several population plans within each municipality.

In terms of interaction, how people join valds is self-organized. This is possible because of the low population density and small settlements in rural areas, therefore people know each other. There is no formal two-way interaction between the valds and the responsible officer at the municipality. Typically, there is only oneway communication: a vald will receive a letter from the municipality detailing their quota for the hunting seasons and providing updates on regulatory changes and requirements, and the vald has to report the annual hunting result. Vald members may meet informally and for the hunt. Within the vald, decisions related to the distribution of hunting licenses and other issues are made by majority of votes typically at an annual meeting.

If valds are part of a population plan area, there will typically be an annual meeting. Members pay a small fee to prepare the plan, which may be partially reimbursed if they apply successfully for funding from the municipality. These funds come from the fee landowners have to pay for every animal harvested toward a municipal wildlife fund that can be used for deer management and research.

There are no fines to landowners for not fulfilling the allocated quota. At a national scale in 2015 , only $62 \%$ of the quota of red 
deer was actually harvested (Statistics Norway). The mismatch between allocations and harvest is typical for all cervid species to varying degrees in the Norwegian management system. An attempt to compensate the low numbers harvested is often to allocate high quotas to ensure a sufficient number are shot. Many landowners value having a high population density of deer, so there is at times an unwillingness to fulfill the hunting quota. This can then result in higher costs related to damage from grazing on agricultural crops (mostly grass production) and browsing on spruce trees of commercial value (Skonhoft et al. 2013).

\section{Methods}

The study was based on a quantitative design (Creswell 2009) to allow the examination of a large sample of the population of landowners whose properties are used for deer hunting in the southwest of Norway. The geographical focus was determined by the location of red deer populations and associated management issues. Figure 1 shows that the number of red deer harvested is by far the highest in the southern part of the country along the west coast. Municipalities targeted in the study are located in the counties Rogaland, Hordaland, Sogn og Fjordane, Møre og Romsdal, and Sør-Trøndelag. The number of red deer harvested in these five counties was 30,628 in the 2015 hunting season, which represents over $90 \%$ of all red deer harvested in Norway.

Fig. 1. The number of red deer harvested in Norwegian municipalities in the 2015/16 hunting season

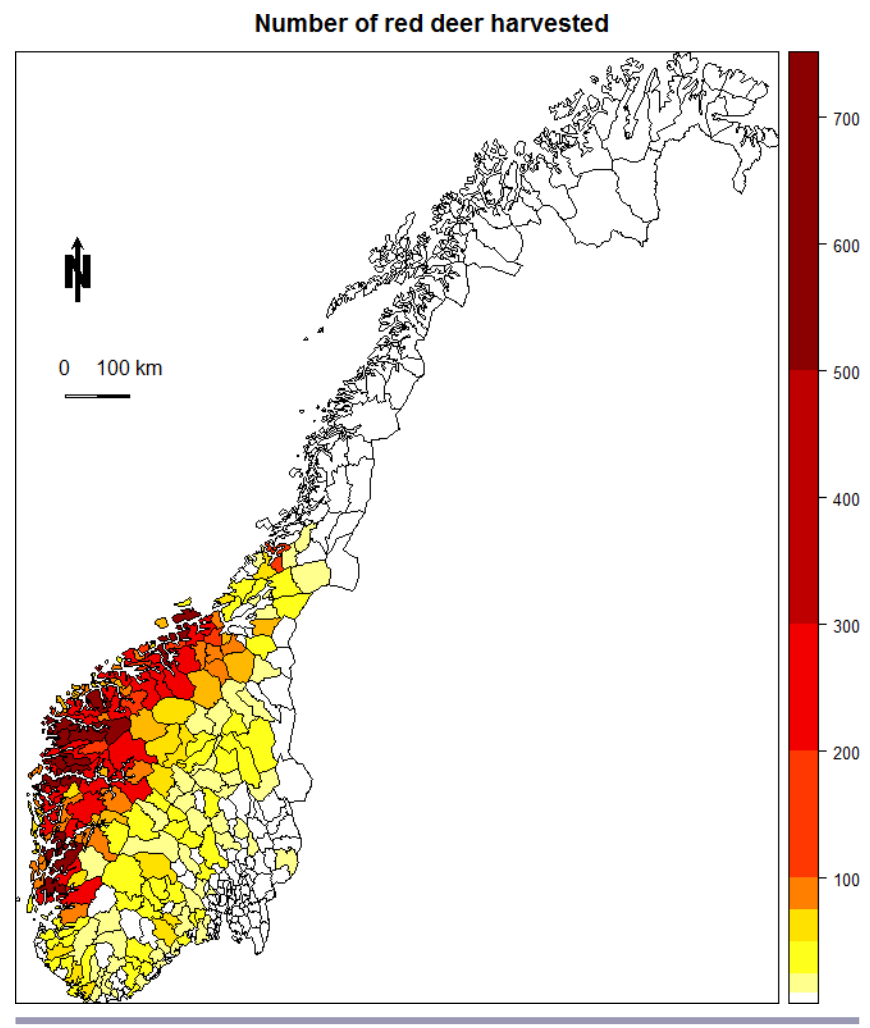

The questionnaire was designed based on previous studies on deer management and hunting behavior (Olaussen and Mysterud, 2012, Andersen et al. 2014), and amended based on insights from informal discussions and comments from a project board consisting of hunters, representatives of landowners, ecologists, and a social scientist. A pilot test was carried out with two landowner representatives. The questionnaire (Appendix 1) included questions on the participant's property, number of deer harvested, their hunting motivation, and opinions about current red deer management and collaboration. To determine the extent to which respondents held a particular attitude or perception, we presented statements that respondents were asked to rate on a 5point Likert scale for their level of agreement or importance. The majority of questions were closed-ended questions, with some open-ended questions used to elicit additional views or experiences (Creswell 2009).

Data collection was carried out via an online survey (in Norwegian) using LimeSurvey software. The timing of the survey in January 2016 was aligned with the end of the hunting season. The hunting season in Norway lasts from 1 September to 23 December. We therefore anticipated that the participating landowners could give an accurate account of the recent hunting season and their experiences.

The link to the online survey was sent to landowner associations who then distributed it amongst their members. We cooperated with the Norwegian Forest Owner Associations (NFOA) and Norwegian Farmers Union (NFU), both organizations with a national coverage of membership. Cooperating with these organizations was expected to increase the likelihood of responses (Fan and Yan 2010). According to the number of email addresses held in their membership databases, the survey invitation was sent out to a total of 5795 members. This number includes 2441 NFU members in the five counties included in this study; approximately 1000 NFOA members in their suborganization Vestskog (covering Rogaland, Hordaland, Sogn og Fjordane counties); and 2354 NFOA members in their suborganization Allskog (covering Møre og Romsdal and Sør-Trøndelag counties). It is therefore not possible to determine the exact population in the study and derive a response rate, or claim representativity of the entire Norwegian landowner population. We received 509 responses but not all completed every question in the survey. The dataset is available as open data from the University of Aberdeen repository using this link: https://doi.org/10.20392/97c5971b-4de7-44b8-

baf3-36cd58b89d55. We have removed any identifiers such as municipality and postcode.

Methods for descriptive statistical analysis included Wilcoxon signed ranks tests to assess statistically significant differences between responses, and correlation assessment to determine the potential presence of linear relationships. Latent class analysis (LCA) was used to discern the underlying typologies (or latent classes) of farmers responding to the survey. LCA is a multivariate technique useful for identifying common patterns amongst multiple variables, e.g., survey questions, and classifying individuals into subgroups based on their responses (Lazarsfeld and Henry 1968). The number of latent classes in the final LC classification model was determined using the Bayesian Information Criterion (BIC) (Schwarz 1978), according to which given two estimated nested models, the model with the lower value of BIC is preferred. R packages ggplot2 (Wickham 2009) and poLCA (Linzer and Lewis 2013) were used to plot the data and run the analysis, respectively. 
Fig. 2. Are you satisfied with how deer management is currently organized? $(n=509 ; \mathrm{NS} / \mathrm{ND}=$ neither satisfied nor dissatisfied). For this figure, categories were collapsed for dissatisfied and very dissatisfied; and for satisfied and very satisfied. Vald $=$ grouping of hunting fields.

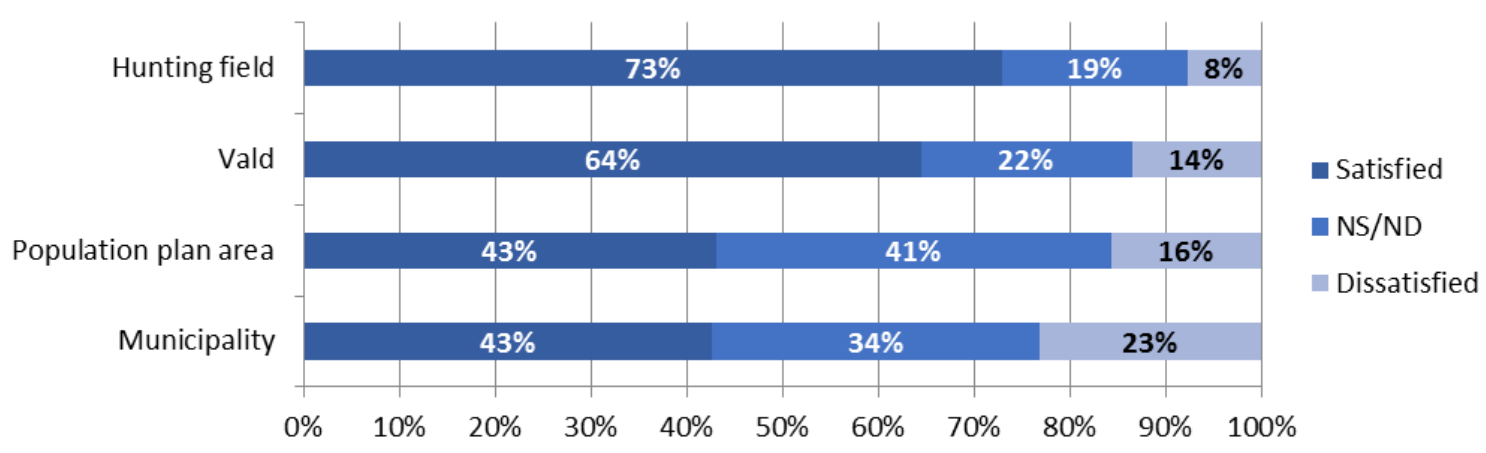

\section{RESULTS}

Characterizing the landowners involved in deer management The survey results showed that the types of Norwegian landowners who responded, and their attitudes to deer management and collaboration, were largely homogeneous. Respondents' income from red deer hunting (including accommodation, guiding, meat sales) was low, with $90 \%$ of respondents earning less than 10,000 NOK annually ( 1000 Euro) and $55 \%$ having no income at all from red deer hunting. The dominant arrangement for hunting was that the landowner and his family, friends, or local hunters are involved in the hunt $(77 \%)$. Only $15 \%$ leased all deer hunting on their property. This result is consistent with an earlier study that found that most red deer hunting is done by the local landowner with relatives and friends, but the landowner may also sell the quota to other hunters (Olaussen and Mysterud 2012).

With the majority of landowners (61\%) involved in hunting activities, and about half ( $48 \%$ ) participating in annual meetings for the hunting field, vald, or population plan area, we can assume that the familiarity with issues of deer management, hunting, quotas, and monitoring is high among respondents. To the majority of landowners $(51 \%)$, the motivation for hunting came from enjoying the practical aspects of the hunt. Social aspects and gaining meat were slightly less important. In contrast, only a minority considered trophies $(5 \%)$ or income from hunting $(12 \%)$ as important. This underlines the hunting tradition in Norway that has been oriented toward meat hunting rather than trophy hunting (Milner et al. 2006).

We identified two types of respondents through LCA: (1) landowners who hunt for enjoyment (70\% of the respondents) and (2) landowners who hunt to reduce damage (30\%). Type 1 landowners saw deer populations as appropriate or too low, a high share of respondents had experienced little or no foraging damage, and they typically had no income from hunting. Type 2 respondents felt very strongly that deer population on their property was too large, a higher share had experienced some or very serious foraging damage by deer (to both pasture and forests), and they tended to have higher income from hunting. These landowners were also more likely to strongly disagree with the suggestion to increase the vald size for better deer management.
They were undecided whether improving cooperation was a necessary aspect of better deer management, even though they were less satisfied with cooperation in the vald than type 1 respondents. Neither age nor gender significantly predicted class membership at 5\% significance level.

\section{Perception of current deer management}

To understand how willing landowners are to change current management, and to embark on more collaborative approaches, we asked for views on current deer management and the quality of collaboration between different institutional levels. In general, landowners were satisfied with how deer management was currently organized. However, there were differences in satisfaction with regard to the level of management (Fig. 2). At the hunting field level, $73 \%$ of respondents were satisfied with current deer management, but this percentage dropped to $43 \%$ at the municipal level. There were statistically significant differences $(\mathrm{p}<0.05)$ between the satisfaction with management at municipality and vald levels. The median value of satisfaction with deer management at vald level is 4 (satisfied), while the median was 3 (neither satisfied nor dissatisfied) for the satisfaction with deer management at municipal level.

In addition, there was a remarkable drop in satisfaction with management at hunting field and vald level, respectively, held by respondents whose vald was less than $5 \mathrm{~km}^{2}$. A similar pattern can be observed for satisfaction with management at population plan and municipal level (Fig. 3a-d). Further to the graphical analysis and in order to establish whether this pattern may be due to fewer landowners in the spatially large valds, we tested the correlation and found that there was a statistically significant correlation between the size of the vald and the number of landowners as can be seen from the correlation values $\left(\mathrm{r}=0.354^{* *}\right.$, significant at $1 \%$ level).

Landowners whose vald consisted of more than 10 hunting fields were more satisfied than valds with fewer hunting fields. The share of satisfied respondents was more than 4 times higher than in valds with less than 10 hunting fields (Fig. 4).

\section{Perception of quality of cooperation}

The trend observed for the satisfaction with current deer management was mirrored in the perception of the quality of cooperation in deer management (Fig. 5). Whereas $66 \%$ of 
Fig. 3. Relative values of levels of satisfaction in relation to the respondents' vald (grouping of hunting fields) size (in square kilometers) at the level of (a) hunting field, (b) vald, (c) population plan area, (d) municipality. NS/ND = neither satisfied nor dissatisfied.
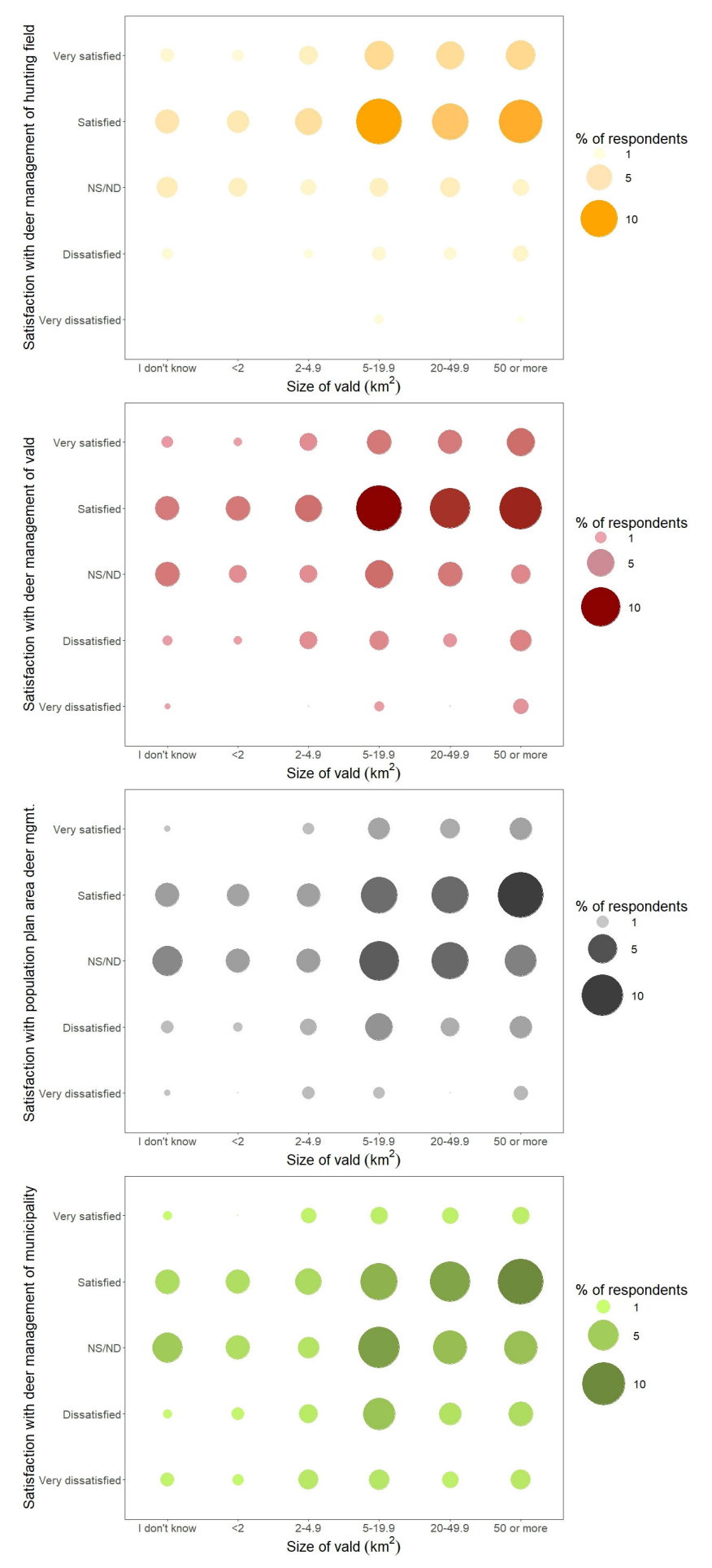

respondents assessed the cooperation among landowners within the hunting field as good to very good, this percentage dropped to $52 \%$ for the quality of cooperation between hunting fields in the same vald, and to $30 \%$ within the population plan area. The larger the scale, the less familiar respondents were with cooperation (increase in share of respondents who answered "I don't know") and the poorer they perceived the quality of cooperation to be. We also found a relationship between respondents' vald size and the perceived quality of cooperation (Appendix 2). Those landowners whose vald is larger than $5 \mathrm{~km}^{2}$ perceived the cooperation in the vald and within the population plan area as better. This may mean they are more experienced in cooperating, or they are in a larger vald because they have recognized the benefits of cooperation.

Fig. 4. Number of hunting fields in vald (grouping of hunting fields) and satisfaction with the deer management in vald. NS/ $\mathrm{ND}=$ neither satisfied nor dissatisfied.

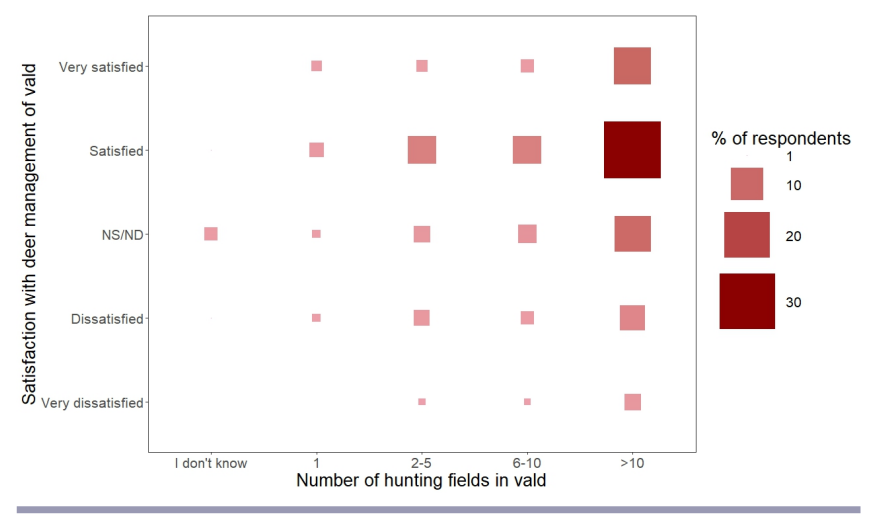

Benefits of and barriers to collaboration

Of the respondents, $60 \%$ and $59 \%$, respectively, also agreed that good management was based on a joint management plan, and means working toward reducing the population in order to lower the cost of grazing damage on pastures

Understanding of good deer management

The understanding among landowners of what constitutes good deer management was closely linked to what they may perceive as a benefit of cooperation. The majority of respondents agreed that good deer management means balancing the deer population with biodiversity and other landscape and conservation goals (73\%, Fig. 6). Agreement with this very broad objective is easy to achieve, and may signal an openness to accepting trade-offs with other objectives. Of the respondents, $60 \%$ and $59 \%$, respectively, also agreed that good management was based on a joint management plan, and means working toward reducing the population in order to lower the cost of grazing damage on pastures. In addition, there was agreement that hunting quotas should be based on monitoring data $(53 \%)$. There were divergent views on specifics such as having a high proportion of calves in the harvest (33\% agreed, 39\% were neutral, 28\% disagreed) and on managing deer numbers to reduce road accidents (39/32/29\%). This indicates that although there is agreement among landowners on some management objectives, their views diverge for others. 
Fig. 5. How would you describe the cooperation in relation to deer management as you currently experience it? $(\mathrm{n}=503 ; \mathrm{vald}=$ grouping of hunting fields).

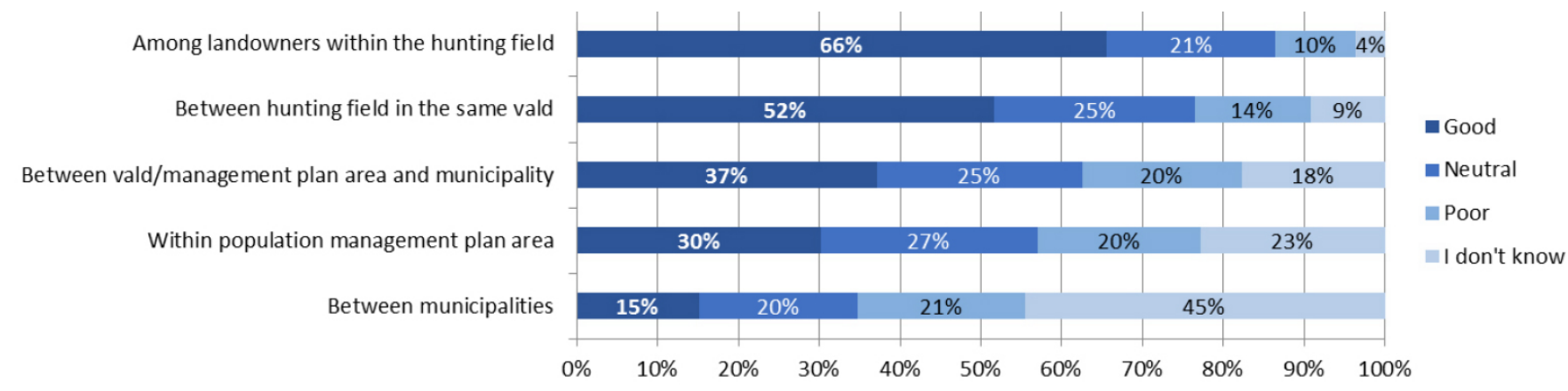

Fig. 6. What does good deer management mean to you? $(n=506 ;$ NA/ND $=$ neither agree nor disagree; hind = adult female deer; stag $=$ adult male deer $)$.

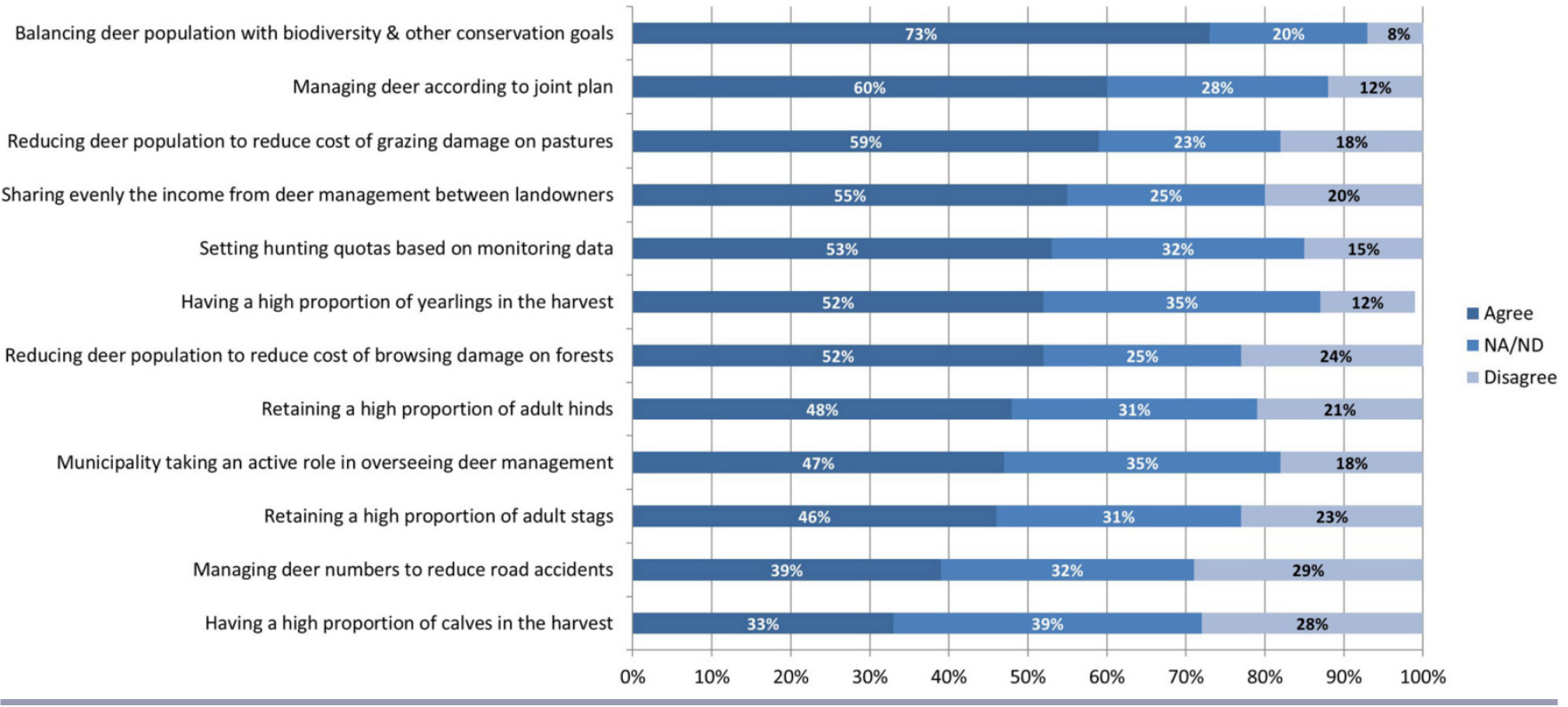

\section{Benefits as motivation for collaboration}

The reasons why Norwegian landowners hunt are important in explaining their motivation for collaboration. Our findings indicate that this sample of Norwegian landowners hunt for enjoyment, socializing, and meat, while aspects such as status or income generation are much less relevant. Therefore, the benefits of collaboration relating to facilitating the practical aspects of the hunt was rated highly by the respondents $(60 \%$ agreed that this was a benefit of cooperation; Fig. 7). Other benefits of collaboration related to specific management aspects, e.g., harvesting the same sex and age classes $(69 \%)$, or shooting the appropriate number of deer on a larger area $(63 \%)$. The statement that collaboration benefits include reduced reporting and administrative duties, as well as increased income from hunting, was rejected by a large share of respondents $(42 \%$ and $53 \%$, respectively, disagreed). This overlaps with the finding that income from hunting is low, and landowners' involvement in hunting is not profit driven.
Although a high share of respondents $(52.6 \%)$ believed that improved cooperation between landowners is necessary for better deer management, only a small proportion thought that increasing the vald size is the way to achieve better management. In fact, $56.1 \%$ disagreed with increasing vald size. This may reflect past (negative) experiences or the lack of experience with cooperation of landowners in smaller valds. There was no correlation to the size of the vald the respondent belonged to. The finding may also be linked with the earlier result of decreasing satisfaction with deer management and collaboration with higher levels of the management.

\section{Barriers to collaboration}

The most commonly cited drawbacks and challenges of collaboration included ecological factors, e.g., the population situation was perceived as too diverse by $39 \%$ of respondents, as well as social and personal factors (Fig. 8). Several of these challenges related to the perception of other landowners. For 
Fig. 7. What is your view on the benefits of cooperation with other landowners? $(n=502$; NA/ND $=$ neither agree nor disagree).

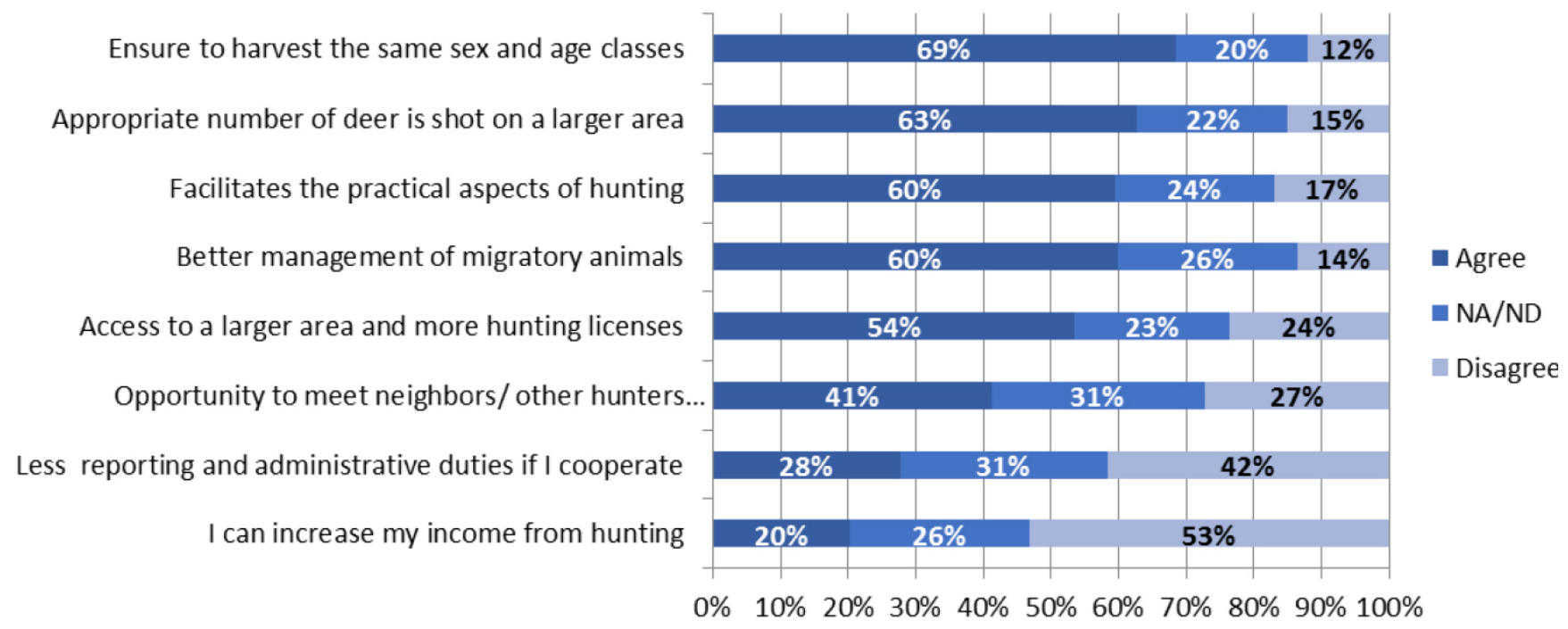

Fig. 8. What is your opinion on potential drawbacks and challenges of cooperation with other landowners related to deer management? $(\mathrm{n}=500, \mathrm{NA} / \mathrm{ND}=$ neither agree nor disagree $)$.

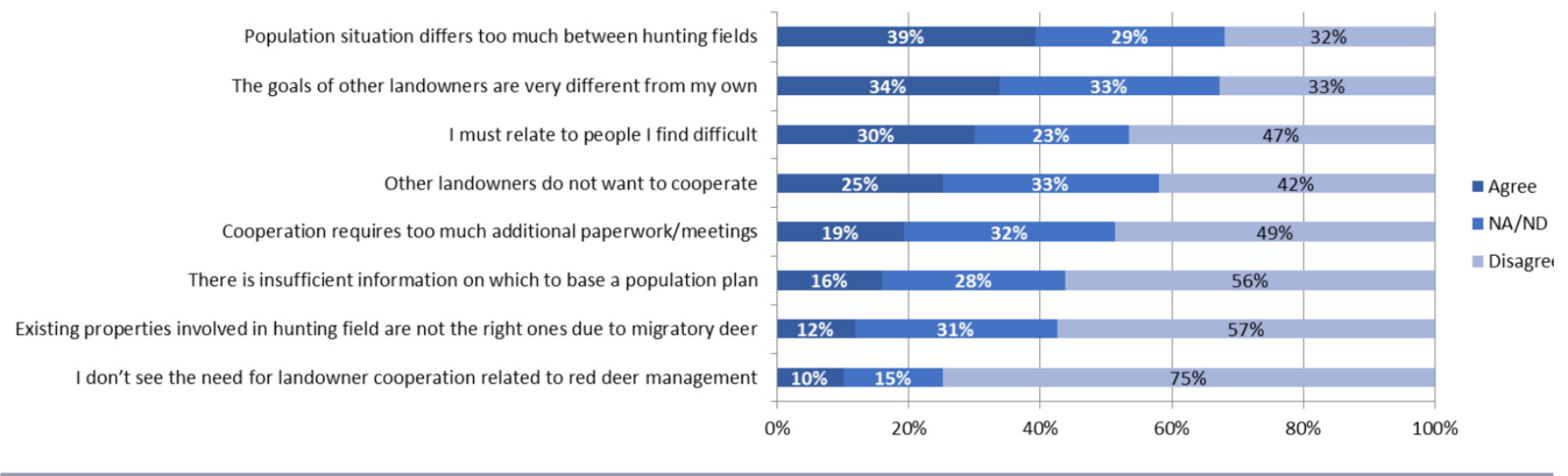

example, the perception that other landowners' goals were different to one's own goals was a potential drawback for $34 \%$ of respondents. However, responses to these statements were not clearly distinct, and there were high shares of respondents who were neutral or disagreed on these statements. A higher share of respondents $(47 \%)$ disagreed that having to relate to people they would find difficult was a drawback to collaboration, and $49 \%$ disagreed that cooperation requires additional paperwork and meetings.

\section{Landowner typology}

We explored whether it is possible to distinguish, through latent class analysis, types of landowners that have similar preferences and attitudes regarding cooperation. Among an initial set of 16 variables (Appendix 3) that explained attitudes and views of cooperation, we selected 7 that defined 2 clearly different sets of preferences (latent classes) and attitudes toward cooperation (BIC $=12126.3$; further reports and probability plots for each of the classes for each variable can be found in Appendix 4).

The typology (Table 1) distinguished those respondents who cooperate when an opportunity arises that they assess as beneficial ("opportunistic cooperators," class 1) and those who have expertise (and positive experiences) in cooperation and know how to utilize it to their advantage ("expert cooperators," class 2). The group of expert cooperators is smaller. Opportunistic cooperators are not per se adverse to cooperation (they disagree that there is no need for cooperation) and they are undecided on some factors that may be barriers to cooperation such as additional paperwork, different goals of other landowners, and diverging deer population. 
Table 1. Characteristics of two classes in the landowner typology and predicted class memberships $(\mathrm{n}=403)$.

\begin{tabular}{ll}
\hline \hline Class 1 (75\%): Opportunistic cooperators & Class 2 (25\%): Expert cooperators \\
\hline $\begin{array}{l}\text { Satisfied with deer management in vald (a grouping of hunting } \\
\text { fields) }\end{array}$ & Satisfied to very satisfied with deer management in vald \\
$\begin{array}{l}\text { Perceive cooperation as neither poor nor good } \\
\text { Undecided whether cooperation requires too much paperwork/ }\end{array}$ & $\begin{array}{l}\text { Perceive cooperation as good to very good } \\
\text { meetings }\end{array}$ \\
$\begin{array}{l}\text { meetings } \\
\text { Disagree and strongly disagree they can increase their income } \\
\text { from hunting through cooperation }\end{array}$ & $\begin{array}{l}\text { Strongly agree they can increasing their income from hunting } \\
\text { through cooperation }\end{array}$ \\
$\begin{array}{l}\text { Undecided whether goals of others are different from their } \\
\text { own }\end{array}$ & $\begin{array}{l}\text { Strongly disagree that goals of others are different from their own } \\
\text { Undecided whether population situation differs too much }\end{array}$ \\
$\begin{array}{l}\text { between hunting fields } \\
\text { Disagree that there is no need to cooperate on deer }\end{array}$ & $\begin{array}{l}\text { Strongly disagree that population situation differs too much } \\
\text { between hunting fields }\end{array}$ \\
management & $\begin{array}{l}\text { Strongly disagree that there is no need to cooperate on deer } \\
\text { management }\end{array}$ \\
\hline
\end{tabular}

\section{DISCUSSION}

We will discuss our findings in light of the literature that suggests "co-management structures and conscious boundary management that includes knowledge co-production, mediation, translation, and negotiation across scale-related boundaries" as a way to addressing complex problems related to scale mismatches (Cash et al. 2006). The first step to resolving scale mismatches is the awareness of the causes of the problem (Cumming et al. 2006), in this case a mismatch between ecological and institutional (social) scales (Meisingset et al. 2018). Our findings indicate that there is already an awareness of this problem with ecologists producing evidence that larger management units are more appropriate relative to movement scales of deer, and municipalities encouraging the creation of larger valds and population plan areas. A large proportion of the Norwegian landowners surveyed have a cooperative mindset (only 10\% do not see a need for landowner cooperation), and already work together to coordinate various aspects of deer management such as hunting, reporting details of animals harvested, and even planning management activities over a longer period in population plans. We found that landowners tend to be satisfied with deer management and the quality of collaboration at the small scale (the hunting field and vald levels). The finding that those who were part of larger valds $\left(>5 \mathrm{~km}^{2}\right.$, and more than 10 hunting fields) were significantly more satisfied with both current deer management and the quality of collaboration, suggests that there is scope to encourage increasing the size of those valds that are currently smaller than $5 \mathrm{~km}^{2}$. Efforts could be made to explore whether smaller valds can be enlarged by adjusting boundaries or amalgamation.

The findings indicate that landowners are more satisfied with current deer management and the cooperation at hunting field and vald levels, because these are the groups with whom they socialize and interact with most regularly, relating to an activity of common interest (the hunt). Landowners are less satisfied with management at municipality level. This is likely because their interaction with representatives from the municipality is more formal, less regular, and has a more "command and control" nature. This interpretation is plausible in the context of literature that identifies trust and tight social networks as essential for successful collaboration (Wondolleck and Yaffee 2000, Plummer and Fitzgibbon 2007). A large share of the respondents know little about cooperation between vald and municipality, or cooperation within the population plan area they are part of. This suggests limited communication and a lack of shared understanding of deer management objectives in different areas and at different institutional levels, which constrains institutional interplay.

The second step in resolving problems related to scale mismatches is to formulate a range of alternative approaches, to solving both the immediate and underlying causes of the mismatch (Cumming et al. 2006). How can nested governance arrangements and institutional interplay be enhanced to support scale alignment? More specifically, who should be undertaking the coordination of deer management, and in what way (plans, incentive payments, or mandatory collective schemes)? Wyborn and Bixler (2013) argue that although trust and social networks are more easily cultivated at the local-scale, relationships among extended networks are crucial to achieve the desired social and ecological outcomes. Ansell and Gash (2008) identify face-to-face dialogue, trust building, and the development of commitment and shared understanding as crucial for collaborative governance. They argue that collaborative forums are successful if they focus on "small wins" that deepen trust, commitment, and shared understanding. We therefore suggest that mechanism for dialogue, sharing information, and interpretation of that information are needed to enhance the relationships between groups of local landowners in the wider population plan area, as well as with the municipality. The agreement on some management objectives should be jointly translated into local management actions. Disagreement over other objectives needs to be negotiated, and decisions made based on the local context.

In addition to mechanisms for dialogue between landowner groups and municipalities, it is also worth exploring the benefits of creating opportunities for interaction between those landowners that are expert cooperators and those that are opportunistic cooperators (Table 1). During such interaction the latter could benefit from knowledge and experience exchange to become more aware of benefits of cooperation, and gain insights 
into how to overcome perceived barriers, or to recognize that these barriers are not of the magnitude that they believed. Because opportunistic cooperators are not per se adverse to cooperation they may only need a gentle nudge, including information and the demonstration of how cooperation works in practice. The learning opportunities should focus on other landowners' goals, the deer population situation, and income opportunities because these are all topics where opportunistic cooperators were undecided. Expert cooperators could alleviate concerns about additional paperwork and meetings, and share their experience of benefits of cooperation, e.g., how they have increased their income from hunting through cooperation. Addressing concerns about neighbors not being interested to collaborate or having different management objectives is important: these aspects were found to be among the most frequently cited barriers to collaborating in agri-environmental management in England (Emery and Franks 2012).

The mechanism for dialogue and learning could be set up by the municipality (either the current staff responsible for deer management and planning, or an additional role), through stakeholder advisory committees (Austin et al. 2014), or an intermediary (or boundary) organization (Cash et al. 2006) as discussed for landscape scale agri-environmental collaboration by Franks (2016). The landowner association, forest owner association, or farmers union may be suitable to adopt this role. Alternatively, independent consultants specialized in facilitation and participatory processes could be deployed, for example, consultants in the network connected to the Norwegian Red Deer Centre at Svanøy (http://www.hjortesenteret.no/).

We suggest that a voluntary approach is likely to be more successful than regulations that prescribe set procedures for deer management. Top-down policy implementation is prone to failure, as shown in other countries, for example, by the difficulties of achieving set hunting quotas in Scotland where local cull targets agreed between the Deer Commission for Scotland and deer management groups are rarely met (MacMillan and Leitch 2008). Austin et al. (2014) found a general distrust of government intervention in Great Britain, and a view that deer managers considered it likely that government legislation would be too general and not sufficiently flexible to account appropriately for the complex set of interrelated, site-specific issues that have to be addressed in practical deer management. Although we did not collect data on the perception of mandatory schemes in Norway, it seems plausible that there is little appetite for a command and control approach, neither amongst landowners, nor municipalities or government bodies, given the historical arrangements for deer management.

\section{CONCLUSION}

In this paper we investigated scale mismatches in social-ecological systems, focussing on the internal dynamics of the social system and its interaction with the ecological system. Using the example of red deer management in Norway we investigated social constraints to collaborative deer management across property boundaries and identified options for addressing the mismatch between migratory deer habitat and administrative boundaries.

The survey of landowners in southwest Norway revealed a number of social constraints. Although landowners were homogenous in that they hunt for enjoyment, socializing, and meat, they hold diverging views on how deer populations should be managed with regard to age and sex classes, and population density. There was some divergence from findings in the literature, for example MacMillan and Leitch (2008), found that Scottish landowners did not have concerns around increasing deer numbers linked to costs of foraging damage to forests and pastures, and increased road accidents.

We also identified a type of landowner that hunts mainly to reduce damage caused by deer. Additional social constraints are the weak structural and personal links between the local landowners and the contact for deer management at municipal level, coupled with a perception that current deer management and cooperation is poorer at higher levels. Partially because of these weak links, a further constraint is the information asymmetry between the local and municipal level, as well as between landowners within a vald. This exacerbates the difficulties associated with maintaining an overview of the deer population situation across a large area, and with determining the optimal boundaries of the area. A further constraint to collaborative deer management are the differing perceptions of the trade-offs between benefits and costs of cooperation. Only $25 \%$ of respondents belong to the class of expert cooperators for whom the advantages of cooperation clearly outweigh the transaction costs.

The differing interests and objectives for deer management, the weak links between actors, the information asymmetry and perceptions of trade-offs can all be addressed through enhanced information flow and facilitated processes to arrive at shared management objectives based on available monitoring data. A number of options for possible intermediaries to support this process are available. Although we already find a cooperative mindset among the majority of the Norwegian landowners surveyed, the role of the intermediary is essential to support institutional interplay and nested governance. That said, it is unlikely that the social constraints related to land tenure and property sizes can be addressed through an intermediary. Because valds are formed in a self-organized manner and gaps in population plan areas may occur because of the voluntary membership arrangements, the alignment of ecological and social scales may require a top down delineation of valds or compulsory population plan membership.

Because income is not a main driver for hunting among Norwegian landowners, we believe that monetary incentives are unlikely to have much effect in changing their attitudes or behavior. However, consideration should be given to additional transaction costs that arise for landowners when they engage in cross-boundary, collaborative deer management. This means that financial support mechanisms are important to cover costs of setting up the population plan, accessing the relevant data, e.g., on deer numbers, and organizing meetings. The less onerous the process of collaboration appears to landowners, the more likely they are to engage. In this way, we can best harness the increasing awareness of landowners who recognize the necessity to manage deer at a larger spatial scale beyond property boundaries and small hunting fields, and the collective and individual benefits of cooperation. 
Responses to this article can be read online at:

http://www.ecologyandsociety.org/issues/responses. $\mathrm{php/10549}$

\section{Acknowledgments:}

This study was funded by the Norwegian Research Council as part of the DeerUnit project (Grant number 230275). We are very grateful to all landowners who took part in the survey. We would also like to acknowledge comments from Vebjørn Veiberg on a previous draft.

\section{LITERATURE CITED}

Adger, W. N., K. Brown, and E. L. Tompkins. 2005. The political economy of cross-scale networks in resource co-management. Ecology and Society 10(2):9. http://dx.doi.org/10.5751/ES-01465-100209

Andersen, O., H. K. Wam, A. Mysterud, and B. P. Kaltenborn. 2014. Applying typology analyses to management issues: deer harvest and declining hunter numbers. Journal of Wildlife Management 78(7):1282-1292. http://dx.doi.org/10.1002/jwmg. 770

Ansell, C., and A. Gash. 2008. Collaborative governance in theory and practice. Journal of Public Administration Research and Theory 18(4):543-571. http://dx.doi.org/10.1093/jopart/mum032

Appolonio, M., R. Andersen, and R. Putman. 2010. European ungulates and their management in the 21st century. Cambridge University Press, Cambridge, UK.

Austin, Z., D. G. Raffaelli, and P. C. L. White. 2013. Interactions between ecological and social drivers in determining and managing biodiversity impacts of deer. Biological Conservation 158:214-222. http://dx.doi.org/10.1016/j.biocon.2012.09.021

Austin, Z., J. C. R. Smart, S. Yearley, R. J. Irvine, and P. C. L. White. 2010. Identifying conflicts and opportunities for collaboration in the management of a wildlife resource: a mixedmethods approach. Wildlife Research 37(8):647-657. http://dx. doi.org/10.1071/WR10057 http://dx.doi.org/10.1071/WR10057

Austin, Z., J. C. R. Smart, S. Yearley, R. J. Irvine, and P. C. L. White. 2014. Incentivising the collaborative management of mobile ecological resources. Land Use Policy 36:485-491. http:// dx.doi.org/10.1016/j.landusepol.2013.09.025

Berkes, F., and C. Folke. 1998. Linking social and ecological systems: management practices and socialmechanisms for buildings resilience. Cambridge University Press, Cambridge, UK.

Cash, D. W., W. Adger, F. Berkes, P. Garden, L. Lebel, P. Olsson, L. Pritchard, and O. Young. 2006. Scale and cross-scale dynamics: governance and information in a multilevel world. Ecology and Society 11(2):8. http://dx.doi.org/10.5751/ES-01759-110208

Creswell, J. W. 2009. Research design. Qualitative, quantitative, and mixed methods approaches. Sage, Los Angeles, California, USA.

Cumming, G. S., D. H. M. Cumming, and C. L. Redman. 2006. Scale mismatches in social-ecological systems: causes, consequences, and solutions. Ecology and Society 11(1):14. http:// dx.doi.org/10.5751/ES-01569-110114
Emery, S. B., and J. R. Franks. 2012. The potential for collaborative agri-environment schemes in England: Can a welldesigned collaborative approach address farmers' concerns with current schemes? Journal of Rural Studies 28(3):218-231. http:// dx.doi.org/10.1016/j.jrurstud.2012.02.004

Fan, W., and Z. Yan. 2010. Factors affecting response rates of the web survey: a systematic review. Computers in Human Behaviour 26(2):132-139. http://dx.doi.org/10.1016/j.chb.2009.10.015

Franks, J. R. 2016. An application of boundary organisation theory to develop landscape-scale conservation in formal agrienvironment schemes. Sociologia Ruralis 56(1):48-73. http://dx. doi.org/10.1111/soru.12059

Gerhardt, P., J. M. Arnold, K. Hackländer, and E. Hochbichler. 2013. Determinants of deer impact in European forests - a systematic literature analysis. Forest Ecology and Management 310:173-186. http://dx.doi.org/10.1016/j.foreco.2013.08.030

Gill, R. 1990. Monitoring the status of European and North American cervids. Global Environment Monitoring System Information Series 8. United Nations Environment Programme, Nairobi, Kenya.

Hothorn, T., and J. Müller. 2010. Large-scale reduction of ungulate browsing by managed sport hunting. Forest Ecology and Management 260(9):1416-1423. http://dx.doi.org/10.1016/j. foreco.2010.07.019

Lazarsfeld, P. F., and N. W. Henry. 1968. Latent structure analysis, Houghton Mifflin, Boston, Massachusetts, USA.

Linzer, D. A., and J. B. Lewis. 2013. poLCA: Polytomous variable latent class analysis. $R$ package version 1.4. http://dx.doi. org/10.18637/jss.v042.i10

MacMillan, D. C., and K. Leitch. 2008. Conservation with a gun: understanding landowner attitudes to deer hunting in the Scottish Highlands. Human Ecology 36(4):473-484. http://dx.doi. org/10.1007/s10745-008-9170-9

MacMillan, D. C., and S. Phillip. 2010. Can economic incentives resolve conservation conflict: the case of wild deer management and habitat conservation in the Scottish Highlands. Human Ecology 38(4):485-493. http://dx.doi.org/10.1007/s10745-010-9332-4

Marshall, G. R. 2008. Community-based, regional delivery of natural resource management: building system-wide capacities to motivate voluntary farmer adoption of conservation practices. Publication No. 08/175. Rural Industries Research and Development Corporation, Kingston, Australia.

Meisingset, E. L., L. E. Loe, Ø. Brekkum, R. Bischof, I. M. Rivrud, U. S. Lande, B. Zimmermann, V. Veiberg, and A. Mysterud. 2018. Spatial mismatch between management units and movement ecology of a partially migratory ungulate. Journal of Applied Ecology 55(2):745-753. http://dx. doi.org/10.1111/1365-2664.13003

Milner, J. M., C. Bonenfant, A. Mysterud, J.-M. Gaillard, S. Csányi, and N. C. Stenseth. 2006. Temporal and spatial development of red deer harvesting in Europe: biological and cultural factors. Journal of Applied Ecology 43(4):721-734. http:// dx.doi.org/10.1111/j.1365-2664.2006.01183.x 
Mysterud, A. 2004. Temporal variation in the number of carkilled red deer Cervus elaphus in Norway. Wildlife Biology 10 (1):203-211. http://dx.doi.org/10.2981/wlb.2004.026

Mysterud, A., L. E. Loe, B. Zimmermann, R. Bischof, V. Veiberg, and E. Meisingset. 2011. Partial migration in expanding red deer populations at northern latitudes-a role for density dependence? Oikos 120(12):1817-1825. http://dx.doi.org/10.1111/

j.1600-0706.2011.19439.x

Mysterud, A., E. L. Meisingset, V. Veiberg, R. Langvatn, E. J. Solberg, L. E. Loe, and N. C. Stenseth. 2007. Monitoring population size of red deer cervus elaphus: an evaluation of two types of census data from Norway. Wildlife Biology 13(3):285-298. http://dx.doi.org/10.2981/0909-6396(2007)13[285:MPSORD]2.0. $\underline{\mathrm{CO} ; 2}$

Olaussen, J. O., and A. Mysterud. 2012. Red deer huntingcommercializing versus availability. European Journal of Wildlife Research 58(3):597-607. http://dx.doi.org/10.1007/s10344-012-0610$\underline{\mathrm{x}}$

Ostrom, E. 1990. Governing the commons. The evolution of institutions for collective action. Cambridge University Press, Cambridge, UK. http://dx.doi.org/10.1017/CBO9780511807763

Plummer, R., and J. Fitzgibbon. 2007. Connecting adaptive comanagement, social learning, and social capital through theory and practice. Pages 38-61 in D. Armitage, F. Berkes, and N. Doubleday, editors. Adaptive co-management: collaboration, learning, and multi-level governance. UBC Press, Vancouver, British Columbia, Canada.

Schwarz, G. 1978. Estimating the dimension of a model. Annals of Statistics 6(2):461-464. http://dx.doi.org/10.1214/aos/1176344136

Skonhoft, A., V. Veiberg, A. Gauteplass, J. O. Olaussen, E. L. Meisingset, and A. Mysterud. 2013. Balancing income and cost in red deer management. Journal of Environmental Management 115:179-188. http://dx.doi.org/10.1016/j.jenvman.2012.11.006

Westerink, J., R. Jongeneel, N. Polman, K. Prager, J. Franks, P. Dupraz, and E. Mettepenningen. 2017. Collaborative governance arrangements to deliver spatially coordinated agri-environmental management. Land Use Policy 69:176-192. http://dx.doi. org/10.1016/j.landusepol.2017.09.002

Wickham, H. 2009. ggplot2: Elegant graphics for data analysis, Springer, New York, New York, USA.

Wondolleck, J. M., and S. L. Yaffee. 2000. Making collaboration work: lessons from innovation in natural resource management. Island, Washington, D.C., USA.

Wyborn, C., and R. P. Bixler. 2013. Collaboration and nested environmental governance: scale dependency, scale framing, and cross-scale interactions in collaborative conservation. Journal of Environmental Management 123:58-67. http://dx.doi.org/10.1016/ j.jenvman.2013.03.014

Young, O. R. 2002 The institutional dimensions of environmental change: fit, interplay, and scale. MIT Press, Cambridge, Massachusetts, USA. 


\section{Appendix 1}

Landowner questionnaire

\section{Deer hunting structures}

1. Deer hunting structure around your property- Please tick the appropriate box in each block.

\begin{tabular}{|l|l|l|l|}
\hline $1 \mathrm{a}$ & Yes & No & $\begin{array}{l}\text { If you tick "no" you will go directly } \\
\text { to question } 16\end{array}$ \\
\cline { 1 - 3 } My property is used for deer hunting & & & \\
\hline
\end{tabular}

1b Jaktfelt

\begin{tabular}{|l|}
\hline A) My property constitutes a separate Jaktfelt \\
\hline B) Our jaktfelt consist of $2-5$ landowners \\
\hline C) Our jaktfelt consist of $6-10$ landowners \\
\hline D) Our jaktfelt consist of $>10$ landowners \\
\hline E) I don't know \\
\hline
\end{tabular}

1c Vald

\begin{tabular}{|l|}
\hline A) Our jaktfelt represents its own vald \\
\hline B) Our vald consists of $2-5$ jaktfelt \\
\hline C) Our vald consists of $6-10$ jaktfelt \\
\hline D) Our vald consists of $>10$ jaktfelt \\
\hline E) I don't know \\
\hline
\end{tabular}

\begin{tabular}{|l|l|l|l|}
\hline $1 \mathrm{~d}$ & Yes & No & I don't know \\
\hline Our vald has a perennial bestandsplan & & & \\
\hline
\end{tabular}




\section{Deer harvested}

2. In 2015; How many red deer were harvested in the Jaktfelt where your property is included? Enter 0 if the specified type of deer were not harvested. Please leave blank if you do not know.

\begin{tabular}{|l|l|l|l|l|l|l|}
\hline & Fawn & $\begin{array}{l}\text { Hind (1.5 } \\
\text { years) }\end{array}$ & $\begin{array}{l}\text { Stag (1.5 } \\
\text { years) }\end{array}$ & $\begin{array}{l}\text { Hind (2.5 } \\
\text { years or older) }\end{array}$ & $\begin{array}{l}\text { Stag (2.5 years } \\
\text { or older) }\end{array}$ & Total \\
\hline $\begin{array}{l}\text { Number of deer } \\
\text { harvested }\end{array}$ & & & & & & \\
\hline
\end{tabular}

3.1 When and how many deer were harvested in your jaktfelt during 2015? Enter 0 if no deer were harvested in the specified period. Please leave blank if you do not know.

\begin{tabular}{|l|l|l|l|l|l|l|l|}
\hline & $\begin{array}{l}1 .-9 . \\
\text { September }\end{array}$ & $\begin{array}{l}\text { 10.-30. } \\
\text { September }\end{array}$ & October & November & December & None & $\begin{array}{l}\text { I don't } \\
\text { know }\end{array}$ \\
\hline $\begin{array}{l}\text { Number of } \\
\text { deer } \\
\text { harvested }\end{array}$ & & & & & & & \\
\hline
\end{tabular}

3.2 What was the total quota for your jaktfelt in 2015?

4. Management authorities recently extended the legal hunting period (2012). What is your opinion on this change?

\begin{tabular}{|l|l|l|l|l|}
\hline & $\begin{array}{l}\text { It is better } \\
\text { now }\end{array}$ & $\begin{array}{l}\text { It does not } \\
\text { matter }\end{array}$ & $\begin{array}{l}\text { It was better } \\
\text { before }\end{array}$ & $\begin{array}{l}\text { I don't } \\
\text { know }\end{array}$ \\
\hline $\begin{array}{l}\text { A) Season start moved forward from 10 } \\
\text { September to 1 September }\end{array}$ & & & & \\
\hline $\begin{array}{l}\text { B) Season end moved back from 15 } \\
\text { November to 23 December }\end{array}$ & & & & \\
\hline
\end{tabular}


5. Do you have migratory deer in your jaktfelt? Mark the most appropriate

\begin{tabular}{|l|l|}
\hline A) No, mainly stationary deer in the area & \\
\hline B) Yes, SOME migratory deer enter throughout the hunting season & \\
\hline C) Yes, MANY migratory deer enter throughout the hunting season & \\
\hline D) Yes, SOME migratory deer disappear from the area throughout the hunting season & \\
\hline E) Yes, MANY migratory deer disappear from the area throughout the hunting season & \\
\hline F) I don't know & \\
\hline
\end{tabular}

\section{Hunting arrangements in general}

6. Who is involved in the actual red deer hunting on your property?

\begin{tabular}{|l|l|}
\hline A) Myself/family/friends/locals hunt ourselves & \\
\hline B) Rent out some periods & \\
\hline C) All the deer hunting at my property is for rent & \\
\hline E) Other: & \\
\hline
\end{tabular}

7. How important are the following aspects of deer hunting to you?

\begin{tabular}{|l|l|l|l|}
\hline & Not important & $\begin{array}{l}\text { Somewhat } \\
\text { important }\end{array}$ & Very important \\
\hline A) The practical part of deer hunting & & & \\
\hline B) Meat from deer hunting & & & \\
\hline C) Trophies from deer hunting & & & \\
\hline D) The social part of deer hunting & & & \\
\hline E) Income from deer hunting & & & \\
\hline
\end{tabular}




\section{Deer management}

8. What is the nature of your current involvement in the management of deer? (Several choices possible):

\begin{tabular}{|l|l|}
\hline A) I participate in the hunt & \\
\hline $\begin{array}{l}\text { B) I am the contact person of Jaktfelt towards vald or I report the number of deer seen } \\
\text { and/or deer harvested ("jaktleder" or serve secretary function) }\end{array}$ & \\
\hline $\begin{array}{l}\text { C) I am involved in administration in the vald (e.g. responsible for vald towards the } \\
\text { municipality, or involved in drawing up the management plan at the vald, ensuring that } \\
\text { management plan objectives are adhered to) }\end{array}$ & \\
\hline D) I am board member of bestandsplanområde (collaboration of several vald) & \\
\hline E) I participate in annual meetings with members of jaktfelt, vald or bestandsplanområde & \\
\hline F) I am not involved in deer management & \\
\hline G) Other: & \\
\hline
\end{tabular}

9. Are you satisfied with how deer management is currently organised?

\begin{tabular}{|l|l|l|l|l|l|}
\hline & $\begin{array}{l}\text { Very } \\
\text { dissatisfied }\end{array}$ & Dissatisfied & $\begin{array}{l}\text { Neither } \\
\text { satisfied } \\
\text { nor } \\
\text { dissatisfied }\end{array}$ & Satisfied & $\begin{array}{l}\text { Very } \\
\text { satisfied }\end{array}$ \\
\hline A) In the jaktfelt area & & & & & \\
\hline B) In the vald area & & & & & \\
\hline $\begin{array}{l}\text { C) In the population plan } \\
\text { area }\end{array}$ & & & & & \\
\hline D) In the municipality & & & & & \\
\hline
\end{tabular}




\section{Benefits and challenges of cooperation}

10. How would you describe the cooperation in relation to deer hunting and management as you currently experience it? $\quad 1=$ Cooperation is very poor- $5=$ Cooperation is very good.

\begin{tabular}{|c|c|c|c|c|c|c|}
\hline & 1 & 2 & 3 & 4 & 5 & $\begin{array}{l}\text { I don't } \\
\text { know }\end{array}$ \\
\hline $\begin{array}{l}\text { A) Among landowners with } \\
\text { jaktfelt }\end{array}$ & & & & & & \\
\hline $\begin{array}{l}\text { B) Between jaktfelt in the s } \\
\text { vald }\end{array}$ & & & & & & \\
\hline $\begin{array}{l}\text { C) Within the } \\
\text { bestandsplanområde }\end{array}$ & & & & & & \\
\hline $\begin{array}{l}\text { D) Between vald/ } \\
\text { bestandsplanområde and } \\
\text { Municipality }\end{array}$ & & & & & & \\
\hline E) Between municipalities & & & & & & \\
\hline
\end{tabular}

11.1. What is your view on the benefits of cooperation with other landowners?

$1=$ Disagree strongly $-5=$ Agree strongly

\begin{tabular}{|l|l|l|l|l|l|}
\hline & 1 & 2 & 3 & 4 & 5 \\
\hline $\begin{array}{l}\text { A) Through cooperation I have access to a larger } \\
\text { area and more hunting licenses }\end{array}$ & & & & & \\
\hline $\begin{array}{l}\text { B) Through cooperation we can ensure to harvest } \\
\text { the same sex and age classes }\end{array}$ & & & & & \\
\hline $\begin{array}{l}\text { C) By cooperating we can ensure that an } \\
\text { appropriate number of deer is harvested on a larger } \\
\text { area }\end{array}$ & & & & & \\
\hline $\begin{array}{l}\text { D) Cooperation leads to a better management of } \\
\text { migratory animals }\end{array}$ & & & & & \\
\hline $\begin{array}{l}\text { E) Cooperation facilitates the practical aspects of } \\
\text { hunting }\end{array}$ & & & & & \\
\hline
\end{tabular}




\begin{tabular}{|l|l|l|l|l|l|}
\hline $\begin{array}{l}\text { F) I can increase my income from hunting if I } \\
\text { cooperate with others }\end{array}$ & & & & & \\
\hline $\begin{array}{l}\text { G) I have less reporting and administrative duties if I } \\
\text { cooperate }\end{array}$ & & & & & \\
\hline $\begin{array}{l}\text { H) Cooperation provides an opportunity to meet } \\
\text { neighbours/ other hunters socially }\end{array}$ & & & & & \\
\hline
\end{tabular}

11.2. Are there any other benefits of cooperation that come to mind? Please specify:

12.1. What is your opinion on potential drawbacks and challenges of cooperation with other landowners related to red deer management? $\quad 1=$ Disagree strongly $-5=$ Agree strongly

\begin{tabular}{|l|l|l|l|l|l|}
\hline & & & & & \\
\hline $\begin{array}{l}\text { A) Cooperation requires too much additional } \\
\text { paperwork/meetings }\end{array}$ & & & & \\
\hline $\begin{array}{l}\text { B) I don't see the need for landowner cooperation } \\
\text { related to red deer management }\end{array}$ & & & & & \\
\hline $\begin{array}{l}\text { C) There is insufficient information on which to base } \\
\text { a bestandsplan }\end{array}$ & & & & & \\
\hline $\begin{array}{l}\text { D) Population situation differs too much between } \\
\text { jaktfelt }\end{array}$ & & & & & \\
\hline $\begin{array}{l}\text { E) The goals of other landowners are very different } \\
\text { from my own }\end{array}$ & & & & & \\
\hline F) Other landowners do not want to cooperate & & & & & \\
\hline G) I must relate to people I find difficult & & & & & \\
\hline $\begin{array}{l}\text { H) Existing landowners involved in jaktfelt are not } \\
\text { the correct ones because of migratory deers }\end{array}$ & & & & & \\
\hline
\end{tabular}


12.2. Are there any other challenges or drawbacks of cooperation that come to mind? Please specify:

\section{Improvements and good deer management}

13. What improvements do you think are necessary in order to achieve better deer management? $1=$ Disagree strongly $-5=$ Agree strongly

\begin{tabular}{|c|c|c|c|c|c|}
\hline & 1 & 2 & 3 & 4 & 5 \\
\hline A) Increase the size of the valds & & & & & \\
\hline $\begin{array}{l}\text { B) Make sure neighbouring valds harvest similar } \\
\text { and age classes }\end{array}$ & & & & & \\
\hline $\begin{array}{l}\text { C) Establish bestandsplan over a larger number } \\
\text { valds }\end{array}$ & & & & & \\
\hline $\begin{array}{l}\text { D) Better monitoring to identify/understand } \\
\text { changes in the deer population }\end{array}$ & & & & & \\
\hline $\begin{array}{l}\text { E) Improved common agreements on managem } \\
\text { aims within the municipality and across municip } \\
\text { borders }\end{array}$ & & & & & \\
\hline $\begin{array}{l}\text { F) We need less detailed quotas in terms of age } \\
\text { sex distribution }\end{array}$ & & & & & \\
\hline $\begin{array}{l}\text { G) More of the stationary animals need to be } \\
\text { harvested }\end{array}$ & & & & & \\
\hline $\begin{array}{l}\text { H) More of the migratory animals need to be } \\
\text { harvested }\end{array}$ & & & & & \\
\hline I) Improve cooperation between landowners & & & & & \\
\hline $\begin{array}{l}\text { J) Municipality should get more involved in deer } \\
\text { management }\end{array}$ & & & & & \\
\hline K) No improvements are necessary & & & & & \\
\hline
\end{tabular}


14. What does "good deer management" mean to you? $1=$ Disagree strongly $-5=$ Agree strongly

\begin{tabular}{|l|l|l|l|l|l|}
\hline & 1 & 2 & 4 & 5 \\
\hline $\begin{array}{l}\text { A) The income from deer management is spread } \\
\text { fairly between landowners }\end{array}$ & & & & & \\
\hline B) Set hunting quotas based on monitoring data & & & & & \\
\hline C) Retaining a high proportion of adult hinds & & & & & \\
\hline $\begin{array}{l}\text { D) Retaining a high proportion of adult stags in the } \\
\text { population }\end{array}$ & & & & & \\
\hline E) Having a high proportion of calves in the harvest & & & & & \\
\hline $\begin{array}{l}\text { F) Having a high proportion of yearlings in the } \\
\text { harvest }\end{array}$ & & & & & \\
\hline $\begin{array}{l}\text { G) Working to reduce deer population to lower the } \\
\text { cost of grazing damage on pastures }\end{array}$ & & & & & \\
\hline $\begin{array}{l}\text { H) Working to reduce deer population to lower the } \\
\text { cost of browsing damage on forests }\end{array}$ & & & & & \\
\hline $\begin{array}{l}\text { I) Managing deer numbers to reduce road accidents. } \\
\text { K) The municipality take an active role in overseeing } \\
\text { other landscape and conservation goals }\end{array}$ & & & & & \\
\hline $\begin{array}{l}\text { J) Managing deer according to a joint management } \\
\text { plan }\end{array}$ & & & & & \\
\hline
\end{tabular}


Size of vald, jaktfelt and property

15. Deer population: (Single tick)

\begin{tabular}{|l|l|l|l|l|}
\hline & Too large & Appropriate & Too low & I don't know \\
\hline $\begin{array}{l}\text { The deer population on my property } \\
\text { is }\end{array}$ & & & & \\
\hline
\end{tabular}

16. In 2015 , the extent of browsing and grazing damage by deer on forest and pastures I own:

\begin{tabular}{|l|l|l|l|l|l|}
\hline & $\begin{array}{l}\text { Serious } \\
\text { damage }\end{array}$ & $\begin{array}{l}\text { Some } \\
\text { damage }\end{array}$ & $\begin{array}{l}\text { Little } \\
\text { damage }\end{array}$ & No damage & $\begin{array}{l}\text { I don't } \\
\text { know }\end{array}$ \\
\hline $\begin{array}{l}\text { A) Browsing damage on } \\
\text { forest }\end{array}$ & & & & & \\
\hline $\begin{array}{l}\text { B) Grazing damage on } \\
\text { pastures }\end{array}$ & & & & & \\
\hline
\end{tabular}

17. The size of your vald (decares)

\begin{tabular}{|c|c|c|c|c|c|}
\hline$<2,000$ & $\begin{array}{l}2,000- \\
4,999\end{array}$ & $\begin{array}{l}5,000- \\
19,999\end{array}$ & $\begin{array}{l}20,000- \\
49,999\end{array}$ & $\begin{array}{l}50,000 \text { or } \\
\text { more }\end{array}$ & I don't know \\
\hline & & & & & \\
\hline
\end{tabular}

18. The size of your jaktfelt (decares)

\begin{tabular}{|l|l|l|l|l|}
\hline$<500$ & $500-1,999$ & $2,000-4,999$ & $5,000-19,999$ & 20,000 or more \\
\hline & & & & \\
\hline
\end{tabular}


19. Size of your property (decares):

\begin{tabular}{|l|l|l|l|l|l|l|l|}
\hline$<50$ & $50-249$ & $250-499$ & $500-999$ & $\begin{array}{l}1,000- \\
1,999\end{array}$ & $\begin{array}{l}2,000- \\
4,999\end{array}$ & $\begin{array}{l}5,000- \\
19,999\end{array}$ & $\begin{array}{l}20,000 \text { or } \\
\text { more }\end{array}$ \\
\hline & & & & & & & \\
\hline
\end{tabular}

\section{Agricultural production}

20. The size of the infield/agricultural area on my property is (decares):

\begin{tabular}{|l|l|l|l|l|l|}
\hline $0-49$ & $50-99$ & $100-199$ & $200-299$ & $300-499$ & 500 or more \\
\hline & & & & & \\
\hline
\end{tabular}

21. The main production on my agricultural area in 2015 consisted of:

\begin{tabular}{|l|l|l|l|l|}
\hline Grass & Arable crops & Vegetables & Fruit/Berries & Other \\
\hline & & & & \\
\hline
\end{tabular}

\section{Income}

22. Gross income (before tax) from red deer hunting (including any accommodation, guiding, meat sales etc.) in 2015 was

\begin{tabular}{|c|c|c|c|c|c|c|c|}
\hline 0 & $\begin{array}{l}1-4,999 \\
k r\end{array}$ & $\begin{array}{l}5,000- \\
9,999 \mathrm{kr}\end{array}$ & $\begin{array}{l}10,000- \\
14,999 \mathrm{kr}\end{array}$ & $\begin{array}{l}15,000- \\
24,999 \mathrm{kr}\end{array}$ & $\begin{array}{l}25,000- \\
49,999 \mathrm{kr}\end{array}$ & $\begin{array}{l}50,000- \\
99,999 \mathrm{kr}\end{array}$ & $\begin{array}{l}100,000 \\
\text { kr or } \\
\text { more }\end{array}$ \\
\hline & & & & & & & \\
\hline
\end{tabular}


23. Please provide an estimate of your total income and any income from your property that apply to you.

\begin{tabular}{|c|c|c|c|c|c|c|c|c|c|}
\hline & 0 & $\begin{array}{l}1- \\
24,99 \\
9 \mathrm{kr}\end{array}$ & $\begin{array}{l}25,000 \\
- \\
49,999 \\
k r\end{array}$ & $\begin{array}{l}50,000 \\
- \\
99,000 \\
k r\end{array}$ & $\begin{array}{l}100,000 \\
- \\
249,999 \\
k r\end{array}$ & $\begin{array}{l}250,000 \\
- \\
399,000 \\
k r\end{array}$ & $\begin{array}{l}400,000 \\
- \\
599,999 \\
k r\end{array}$ & $\begin{array}{l}600,00 \\
0 \mathrm{kr} \text { or } \\
\text { more }\end{array}$ & $\begin{array}{l}\text { Prefe } \\
r \text { not } \\
\text { to say }\end{array}$ \\
\hline $\begin{array}{l}\text { A) Total Gross } \\
\text { income(befor } \\
\text { e tax) from } \\
\text { any source in } \\
\text { 2015: }\end{array}$ & & & & & & & & & \\
\hline $\begin{array}{l}\text { B) Gross } \\
\text { income from } \\
\text { forestry in } \\
\text { 2015: }\end{array}$ & & & & & & & & & \\
\hline $\begin{array}{l}\text { C) Gross } \\
\text { income from } \\
\text { forestry in } \\
\text { normal years: }\end{array}$ & & & & & & & & & \\
\hline $\begin{array}{l}\text { D) Gross } \\
\text { income from } \\
\text { agriculture } \\
\text { (including } \\
\text { livestock) in } \\
\text { 2015: }\end{array}$ & & & & & & & & & \\
\hline
\end{tabular}

\section{Personal data}

Please provide some personal data.

24. Gender:

\begin{tabular}{|l|l|l|l|}
\hline Female & & Male & \\
\hline
\end{tabular}

25. Age

\begin{tabular}{|l|l|l|l|l|}
\hline $18-29$ years & $30-39$ years & $40-49$ years & $50-59$ years & $60+$ years \\
\hline & & & & \\
\hline
\end{tabular}


26. Location of your property

\begin{tabular}{|l|l|}
\hline A) County & \\
\hline B) Municipality & \\
\hline C) Zip code for your property & \\
\hline
\end{tabular}

27. Do you live on the property this questionnaire refers too?

\begin{tabular}{|l|l|}
\hline A) Yes, all year & \\
\hline B) Yes, part of the year & \\
\hline C) No & \\
\hline
\end{tabular}




\section{Appendix 2}

Figure A2.1a-d: Relative values of quality of cooperation in relation to the respondents' vald size (in square kilometres) within (a) hunting field, (b) vald, (c) population plan area, (d) between vald, population plan area and municipality (NP/NG = neither poor nor good).
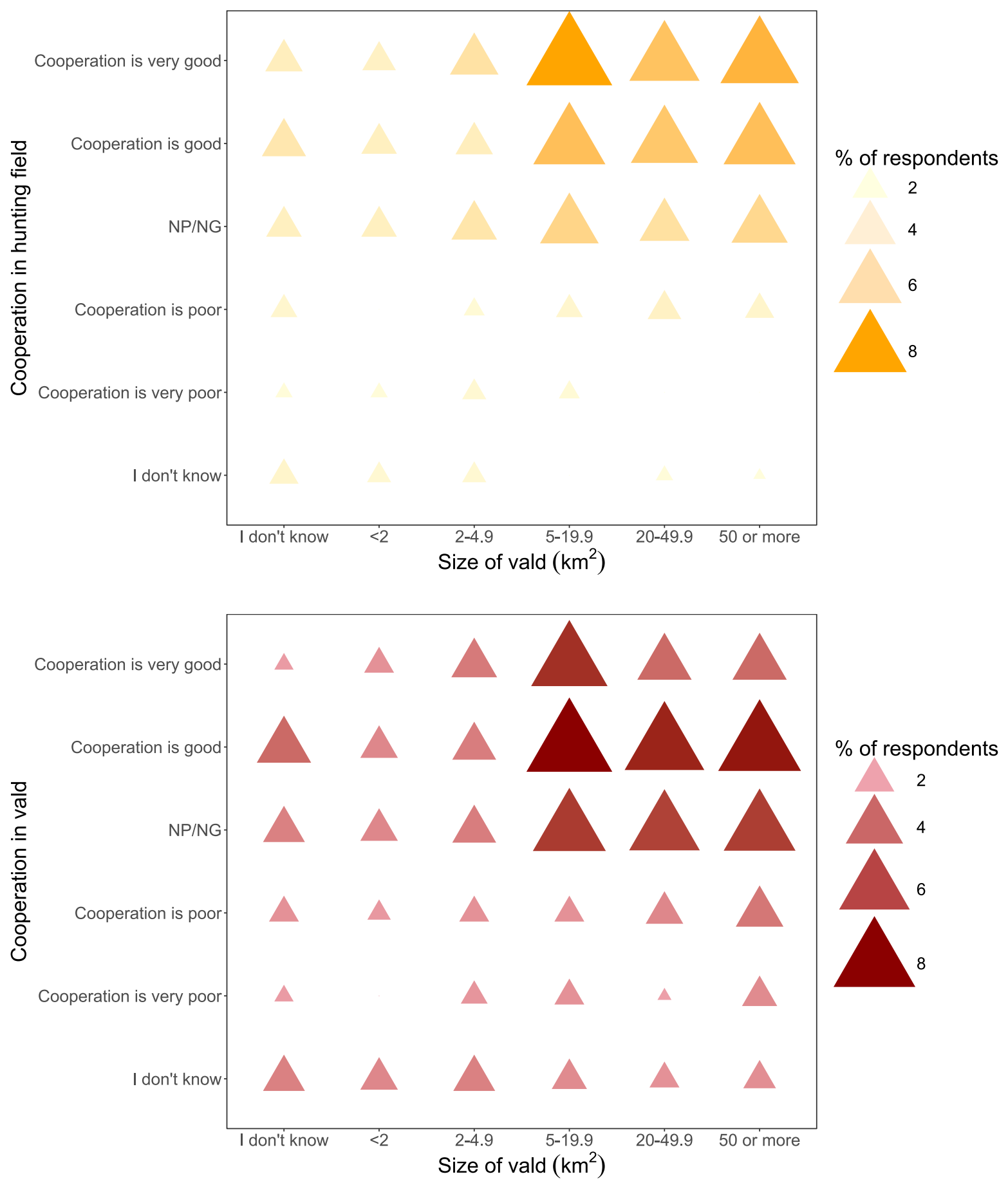

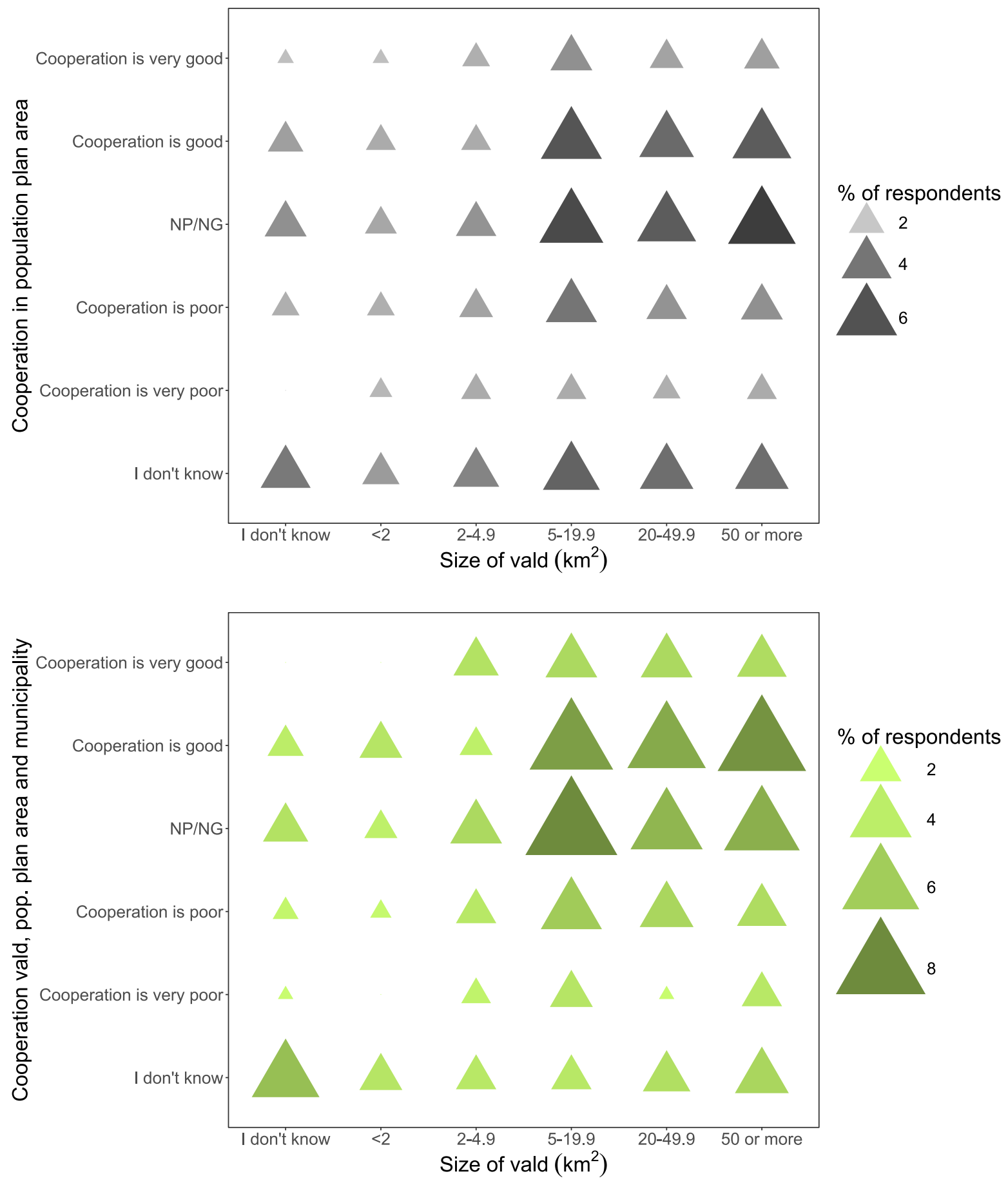


\section{Appendix 3}

List of the 16 variables used in the Latent Class Analysis. Final variables for the landowner typology regarding preferences and attitudes to cooperation in bold.

- Q6A own involvement in hunting

- Q9B satisfaction deer management (Are you satisfied with how deer management is currently organised?)

- Q10B cooperation within vald (How would you describe the cooperation in relation to deer hunting and management between jaktfelt in the same vald, as you currently experience it?)

- Q11.1E practical aspects

- Q11.1F increase income from hunting

- Q12.1A too much paperwork (Do you agree that cooperation requires too much additional paperwork/ meetings?)

- Q12.1B no need for cooperation (Do you agree that there is no need for landowner cooperation in red deer management?)

- Q12.1D. Population situation differs too much between hunting fields

- Q12.1E The goals of other landowners are very different from my own

- Q12.1F Other landowners uncooperative

- Q13A increase vald size (What improvements do you think are necessary to achieve better deer management?)

- Q13I Improve cooperation (What improvements do you think are necessary to achieve better deer management?)

- Q15 deer population (Is the deer population too large?)

- Q16A browsing damage on pasture (Is there serious browsing damage?)

- Q22 income from hunting (What is your income from hunting?

- Q27 resident in property 


\section{Appendix 4}

Latent Class Analysis (LCA) and Latent Class regression with size of vald. The conditional item response probabilities for the 2 latent classes for the 7 variables are plotted in Figure A4.1a-g and LCA fit is summarised in Table A4.1.

Figure A4.1a-g: Conditional item response probabilities, for each class, by (a) cooperation between jakfelt (hunting field) in same vald,(b) cooperation requiring too much paperwork, (c) need for landowners cooperation, (d) satisfaction with deer management in the vald area, (e) increased hunting income from cooperation, (f) differences in landowners' management goals, (g) population situation differing between hunting fields (Class $1=$ 'opportunistic co-operators', class 2 = 'expert cooperators'. NP/NG = neither poor nor good; ND/NA = neither disagree nor agree; ND/NS = neither dissatisfied nor satisfied).

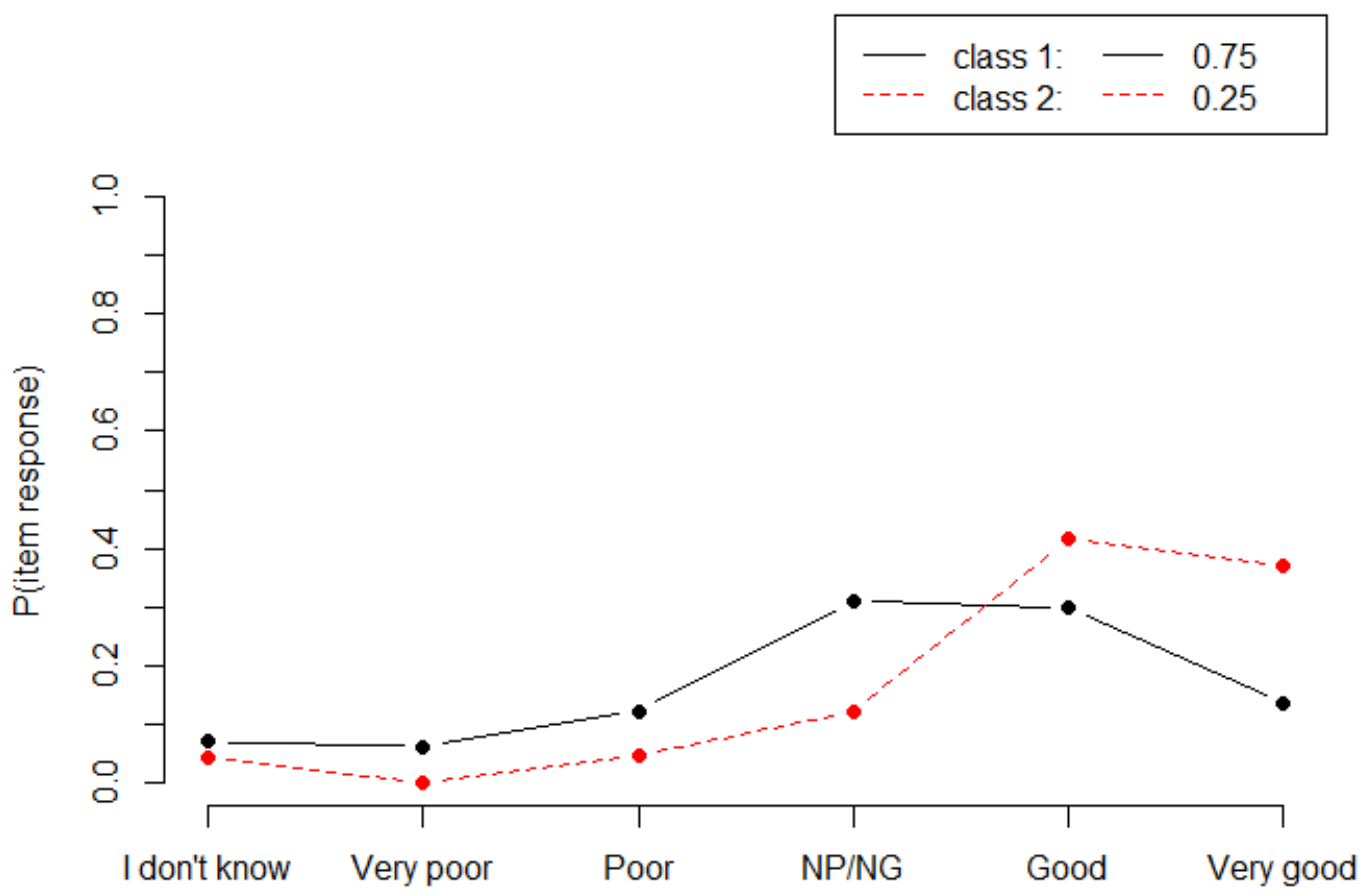

Cooperation on deer hunting and management between.jaktfelt in same vald 

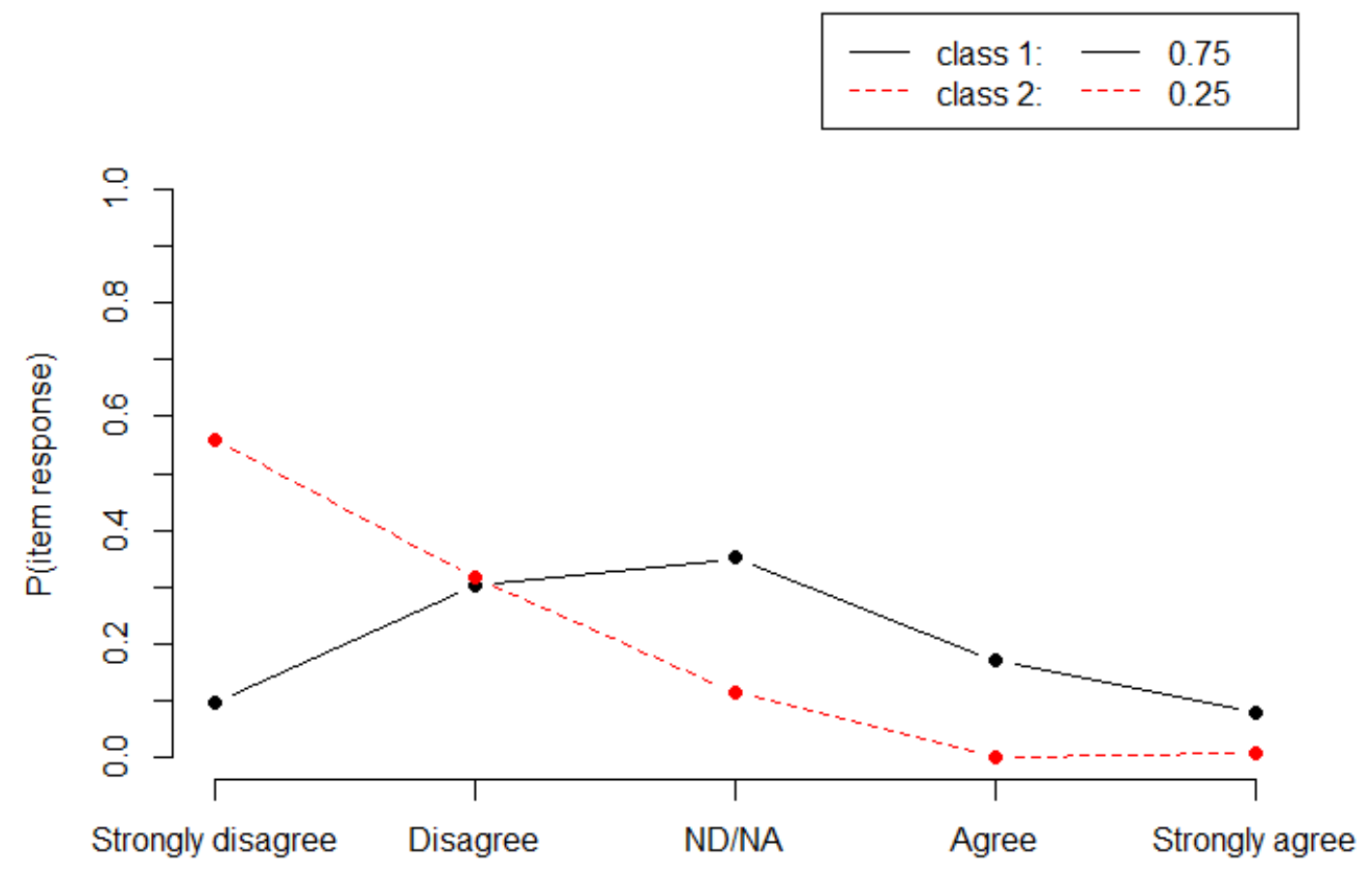

Cooperation requires too much additional paperwork

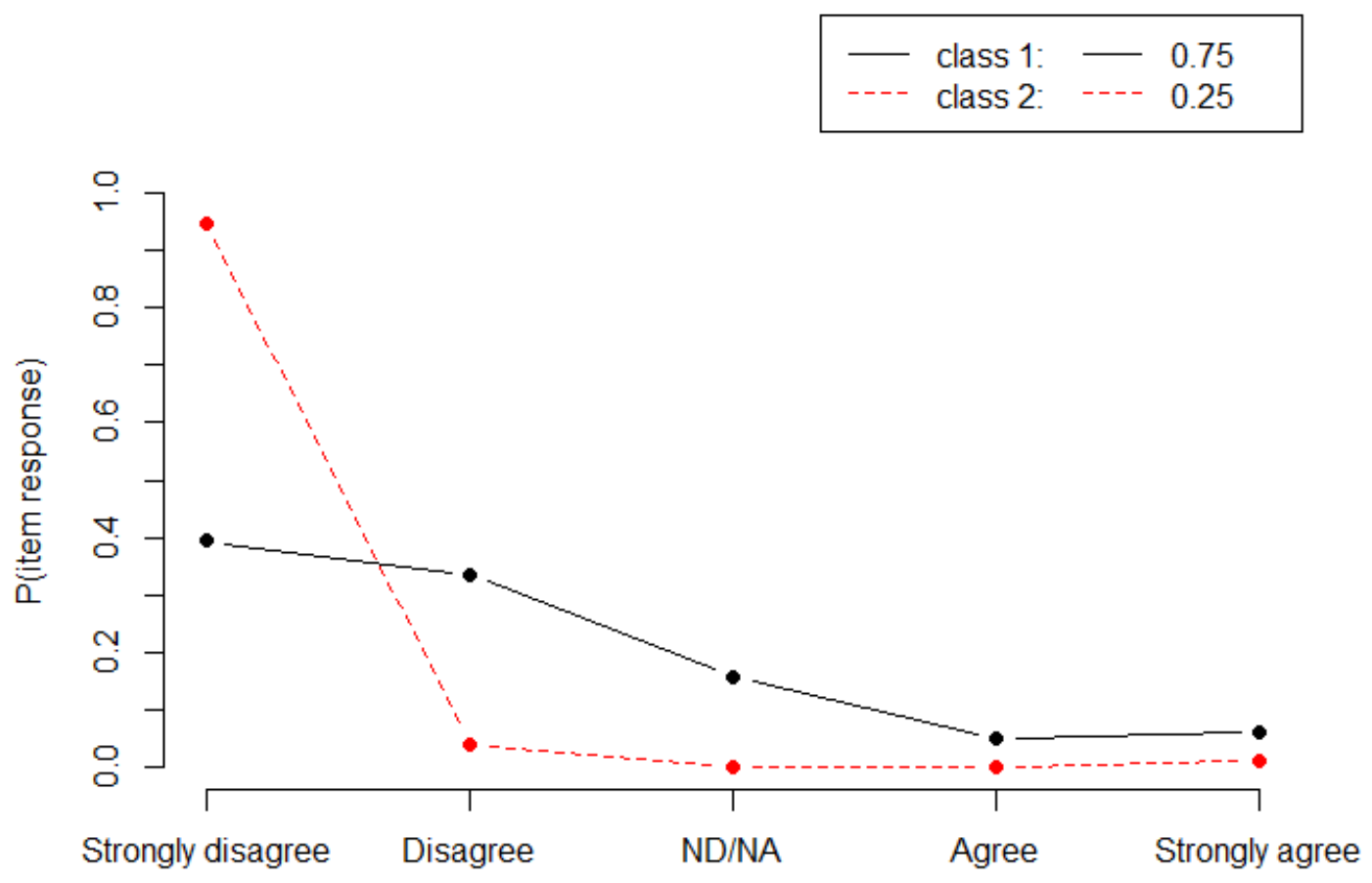

No need for landowner cooperation on red deer management 

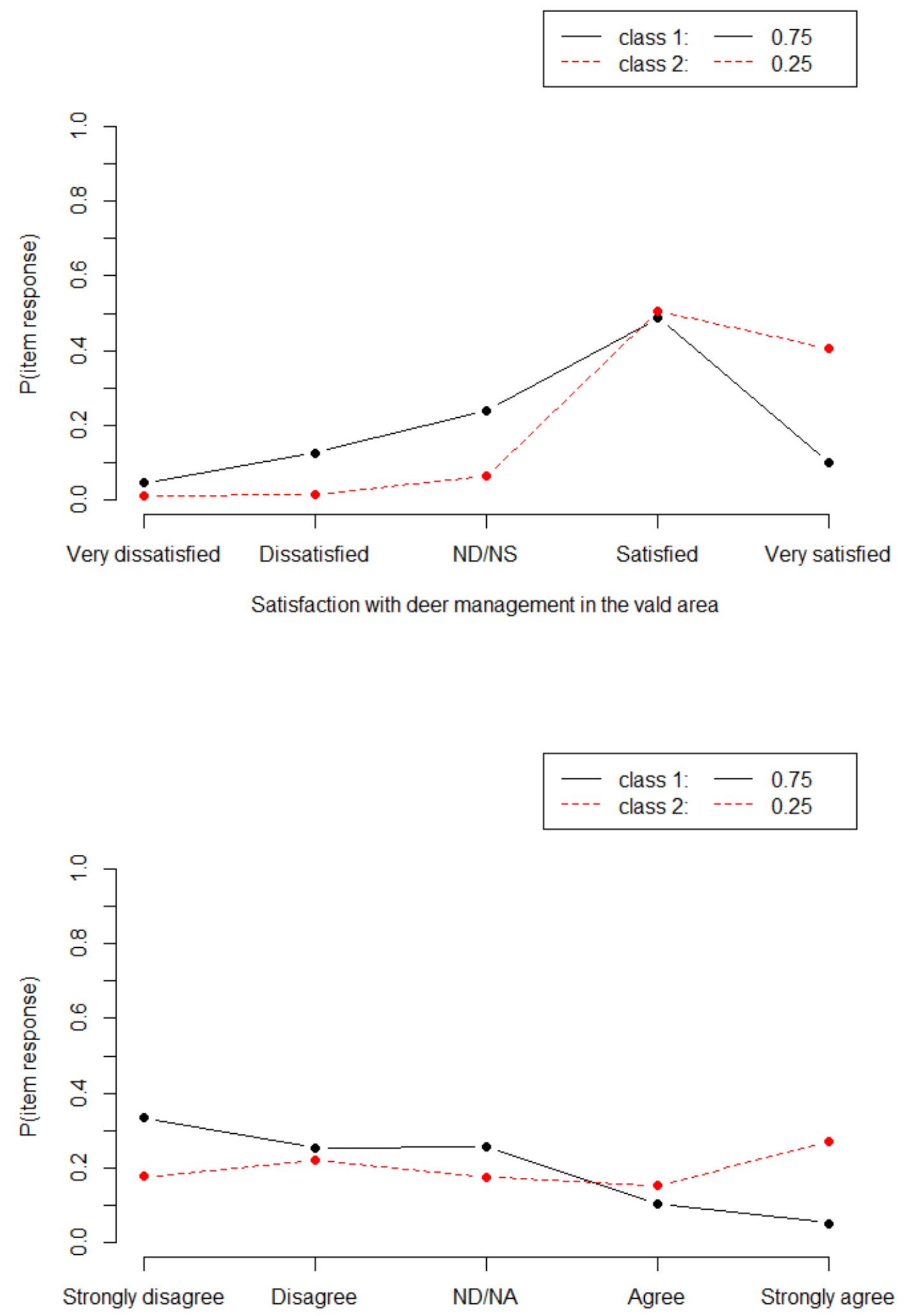

I can increase my income from.hunting if I cooperate with others 


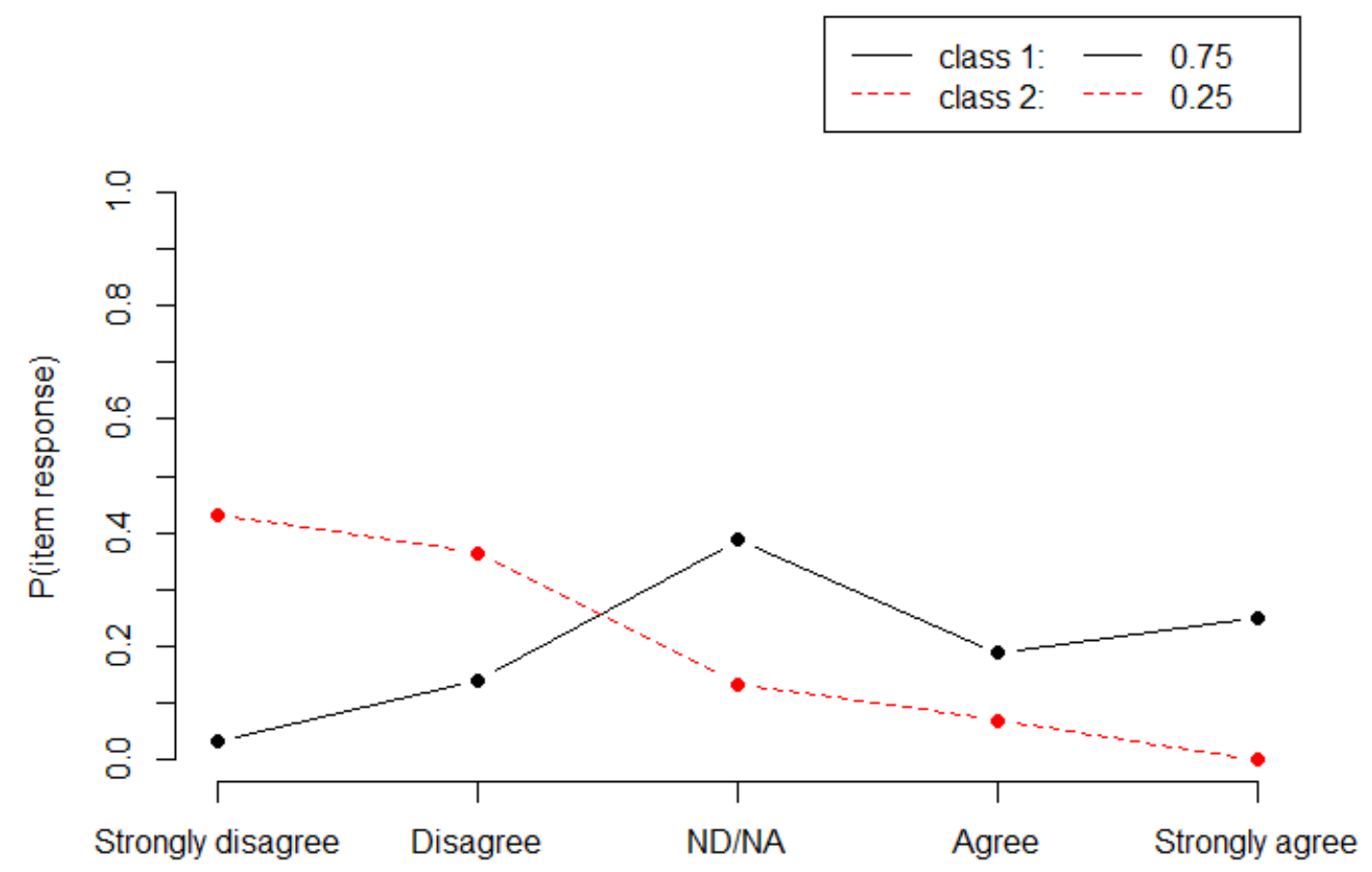

The goals of other landowners are very different from my own

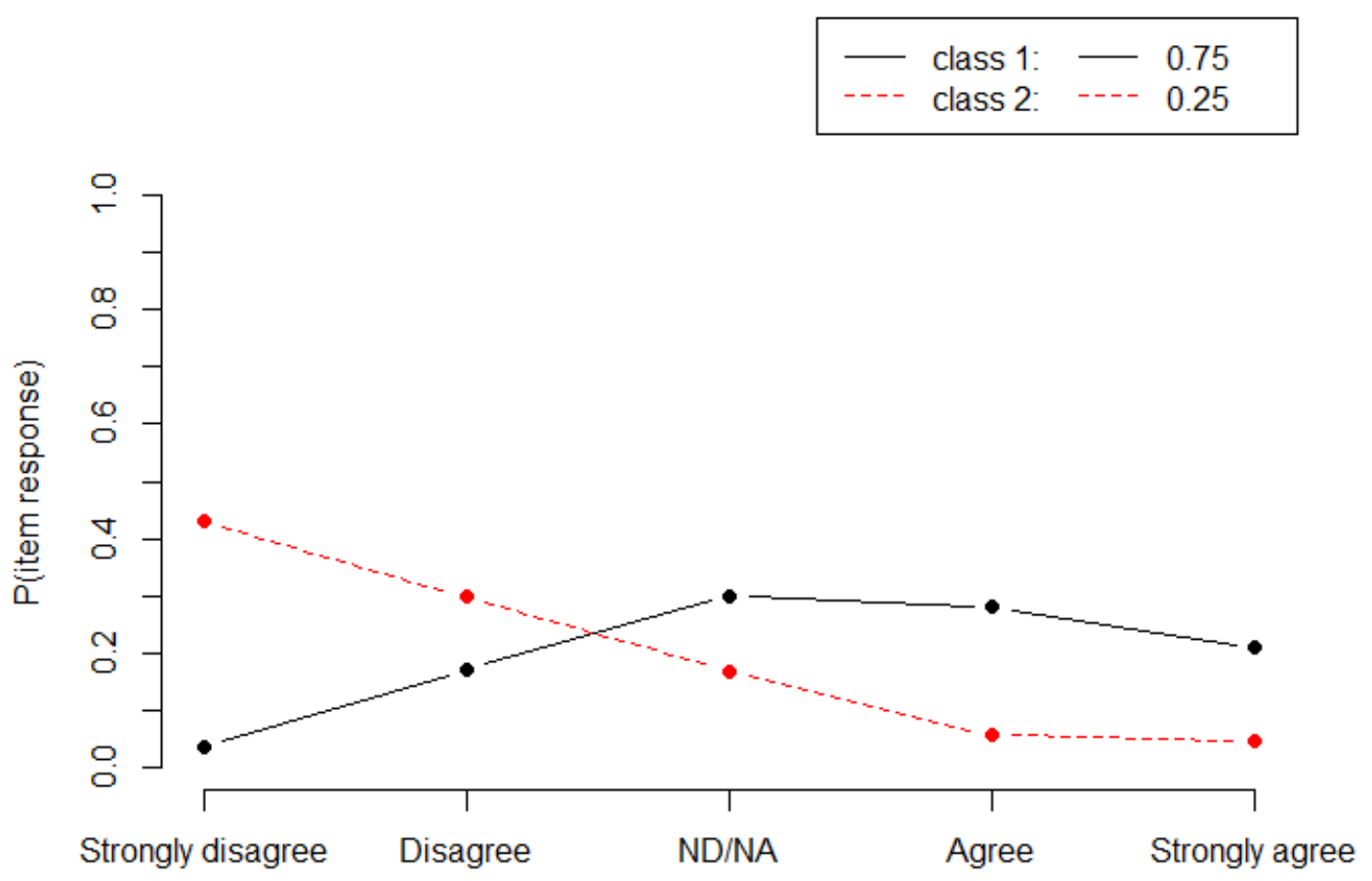

Population situation differs too much between hunting fields 
Table A4.1: LCA fit

\begin{tabular}{lc}
\hline AIC & $8,099.305$ \\
BIC & $8,335.243$ \\
$\mathbf{X}^{2}$ & $125,034.300$ \\
\hline
\end{tabular}

\section{Latent Class regression according to size of vald}

Although the plot of the predicted prior probabilities of latent class membership at varying sizes of the valds (see Figure A4.2) seems to show that the higher the vald size, the more likely the respondent is to belong to class 2 (expert co-operators), we concluded from the results from the LC regression (Table A4.2) that the size of vald does not significantly predict class membership.

Figure A4.2: Probability of latent class membership by vald size.

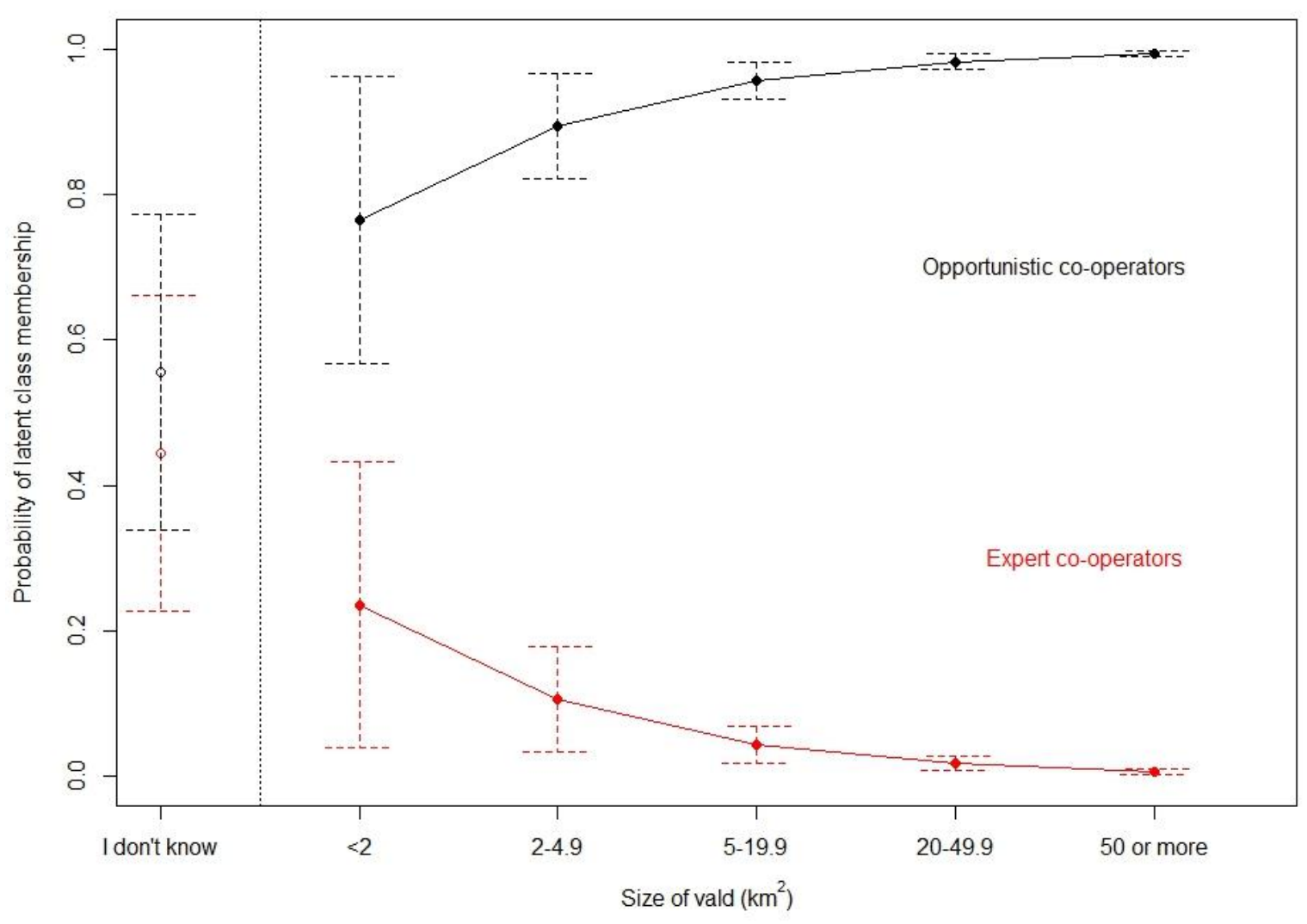


Table A4.2: LC regression for varying levels of size vald $(n=402)$

\begin{tabular}{lcccc}
\hline \hline & Estimate & Std. error & t value & $\operatorname{Pr}(>|\mathbf{t}| \mathbf{)}$ \\
\hline $\mathbf{2} \mathbf{~ k m}^{\mathbf{2}}$ & -0.154 & 0.836 & -0.185 & 0.854 \\
$\mathbf{2 - 4 . 9} \mathbf{~ k m}^{\mathbf{2}}$ & 0.132 & 0.677 & 0.194 & 0.846 \\
$\mathbf{5 - 1 9 . 9} \mathbf{~ k m}^{\mathbf{2}}$ & 0.306 & 0.570 & 0.537 & 0.592 \\
$\mathbf{2 0 - 4 9 . 9} \mathbf{~ k m}^{\mathbf{2}}$ & 0.569 & 0.569 & 1.001 & 0.318 \\
$\mathbf{5 0} \mathbf{~ k m}^{2}$ or more & 0.955 & 0.547 & 1.744 & 0.082 \\
$\mathbf{A I C}$ & $8,084.507$ & & & \\
$\mathbf{B I C}$ & $8,340.280$ & & & \\
$\mathbf{X}^{\mathbf{2}}$ & $125,538.300$ & & & \\
\hline
\end{tabular}

